\title{
What is the role of institutional investors in corporate capital structure decisions? A survey analysis
}

DOI:

10.1016/j.jcorpfin.2019.05.001

\section{Document Version}

Accepted author manuscript

Link to publication record in Manchester Research Explorer

\section{Citation for published version (APA):}

Brown, S., Dutordoir, M., Veld, C., \& Veld-Merkoulova, Y. (2019). What is the role of institutional investors in corporate capital structure decisions? A survey analysis. Journal of Corporate Finance, 58, 270-286.

https://doi.org/10.1016/j.jcorpfin.2019.05.001

\section{Published in:}

Journal of Corporate Finance

\section{Citing this paper}

Please note that where the full-text provided on Manchester Research Explorer is the Author Accepted Manuscript or Proof version this may differ from the final Published version. If citing, it is advised that you check and use the publisher's definitive version.

\section{General rights}

Copyright and moral rights for the publications made accessible in the Research Explorer are retained by the authors and/or other copyright owners and it is a condition of accessing publications that users recognise and abide by the legal requirements associated with these rights.

\section{Takedown policy}

If you believe that this document breaches copyright please refer to the University of Manchester's Takedown Procedures [http://man.ac.uk/04Y6Bo] or contact uml.scholarlycommunications@manchester.ac.uk providing relevant details, so we can investigate your claim.

\section{OPEN ACCESS}




\title{
What is the role of institutional investors in corporate capital structure decisions?
}

\section{A survey analysis}

\author{
Stephen Brown* \\ Marie Dutordoir** \\ Chris Veld*** \\ Yulia Veld-Merkoulova**** \\ February 7, 2019
}

\begin{abstract}
We survey institutional investors about their role in capital structure decisions and views on capital structure theories. Over $82 \%$ of investors believe they influence corporate capital structure decisions, especially for smaller, younger, and more financially constrained firms. Unlike corporate managers, investors consider agency costs of free cash flow important drivers of capital structure. Investors' responses also support pecking order and market timing theories. Most investors find financial constraints important, with components of the Kaplan-Zingales and Whited-Wu indexes dominating other proxies. Overall, our findings suggest a first-order impact of investor preferences on capital structure decisions.
\end{abstract}

Keywords: Capital structure; capital supply; institutional investors; security issuance; security design; financial constraints.

* David S. Loeb Professor of Finance, Stern School of Business, New York University, and Professor of Finance, Monash Business School, Monash University; e-mail sbrown@stern.nyu.edu and stephen.brown@monash.edu.

** Professor of Finance, Alliance Manchester Business School, University of Manchester; e-mail marie.dutordoir@manchester.ac.uk.

*** Professor of Finance, Monash Business School, Monash University; e-mail chris.veld@monash.edu.

**** Professor of Finance, Monash Business School, Monash University; e-mail yulia.veldmerkoulova@monash.edu.

We thank the following academic colleagues for their suggestions on the questionnaire design: Amedeo de Cesari, Abe de Jong, Vidhan Goyal, Campbell Harvey, Maria-Teresa Marchica, Konstantinos Stathopoulos, Norman Strong, and George Wang. In addition, we thank Yangyang Chen, Thomas Chemmanur, Kevin Davis, Abe de Jong, Frederik Schlingemann, Gary Twite, Betty Wu, Luana Zaccaria, and participants at research seminars at Banca d'Italia, Rotterdam School of Management, University of Glasgow, University of Manchester, University of Melbourne, and the JCF Special Issue Conference on "The Role of Institutional Investors in Corporate and Entrepreneurial Finance" for their helpful comments and suggestions. The following practitioners also gave helpful comments on the survey: Paul Benveniste, Nick Chapman, Paul Greenwood, Matthew Lambert, and Nikola Pike. Tim Kooijmans provided excellent research assistance. The authors acknowledge financial support from the Australian Centre for Financial Studies and CPA Australia. 


\section{Introduction}

Despite many years of research, the finance literature does not agree on whether there is an optimal capital structure or on the related question of how companies choose between different securities. Traditionally, most capital structure theories have focused on the corporate demand for capital. These rationales, which include static trade-off (Kraus and Litzenberger, 1983), pecking order (Donaldson, 1961; Myers and Majluf, 1984), and market timing theories (Stein, 1996; Baker and Wurgler, 2002) all reason from the point of view of companies trying to attract capital. Similarly, most empirical studies tend to focus on the corporate side, without finding conclusive evidence. ${ }^{1}$

Several studies argue that corporate finance actions can also be influenced through investor (supply) rather than corporate (demand) channels (Faulkender and Petersen, 2006; Leary, 2009; Lemmon and Roberts, 2010). These studies typically use proxy variables derived from financial statements or market data to capture capital supply and investor preferences.

Our study takes a different approach. We directly ask institutional investors about their potential influence and views on corporate capital structure decisions, through survey analysis. ${ }^{2}$ Institutional investors have become major players in global capital markets, spurred by factors such as financial innovation, weakened bank balance sheets following the financial crisis, and stricter bank regulation (IMF, 2016). We focus on Australian investors to achieve a sufficiently high response rate and generate more detailed answers to the open questions in our survey. Capital structure in Australia is representative of that in other developed countries. ${ }^{3}$ The only

\footnotetext{
${ }^{1}$ For example, some studies confirm pecking order theory (Shyam-Sunder and Myers, 1999; Hovakimian et al., 2001; Dong et al., 2012), while some reject it (Frank and Goyal, 2003, Leary and Roberts, 2005; Fama and French, 2005), and some find mixed evidence (Graham and Harvey, 2001; De Jong and Verwijmeren, 2010). Similarly, some studies find strong evidence that managers try to time the equity market (Graham and Harvey, 2001; Baker and Wurgler, 2002; Brounen et al. 2004, 2006; Gomes and Philips, 2012; Dong et al., 2012), while others find very little evidence of equity market timing (Jung et al., 1996; DeAngelo et al., 2010).

${ }^{2}$ In our paper, capital structure decisions include decisions on what debt ratio to maintain, which security types to issue, and how to design these securities. We often refer to 'institutional investors' as 'investors' for brevity.

${ }^{3}$ De Jong et al. (2008) find that the median leverage of Australian companies is of the same order of magnitude as that of United States (U.S.) companies. Fan et al. (2012) present similar results for debt maturity. Australia has
} 
relevant difference with the typical U.S. research setting pertains to Australia's dividend imputation system. Under this system, domestic corporate taxes are distributed to eligible shareholders as a tax credit with dividend payments, reducing the attractiveness of corporate debt from a tax perspective (Twite, 2001; Pattenden, 2006). ${ }^{4}$ Regarding the capital supply side, Australia has a ratio of (non-bank) institutional investor assets to bank assets of the same order of magnitude as Euro zone countries and the U.K., i.e. approximately $100 \%$. This suggests a similar degree of bank disintermediation between Australia and these countries (IMF, 2016). ${ }^{5}$

In total, 275 individual investors responded to our survey, corresponding to an overall response rate of $16.1 \%$. In the first set of questions, we examine investors' perceptions of their impact on capital structure decisions. We find that more than $82 \%$ of the respondents believe they play a strong role in the capital structure decisions of the companies in which they invest or are contemplating investing. On average, they estimate that their influence on capital structure is approximately equal in magnitude to that of firm and macroeconomic characteristics. In terms of channels of influence, approximately one-third of the investors only talk directly with corporate management (31\%), while approximately one-fifth of the investors (19\%) only talk with investment banks and not with the company. Approximately half of the investors use both mechanisms of influence (47\%). In an open question, we ask investors which companies they believe are most susceptible to investor influence regarding capital structure decisions. Their answers suggest that smaller, younger, and financially constrained firms are more likely to experience an investor impact. In addition to these firm characteristics, investors

\footnotetext{
a well-developed financial reporting system, of the same level of quality as countries such as Canada, France, Germany, and the United Kingdom (U.K.) (Degeorge et al., 2013).

${ }^{4}$ Dividend imputation systems are not unique to Australia. They are also adopted in countries like Canada, France, Germany, New Zealand, and the U.K., with differences across countries in the extent to which corporate taxes can be distributed to shareholders as a credit (Twite, 2001).

${ }^{5}$ For comparison, the correspondent ratio for the U.S. is around $250 \%$. This much larger ratio may be attributable to the process of bank disintermediation starting much earlier in the U.S. than in other countries (IMF, 2016).
} 
highlight the nature of their relation with the firm as well as market conditions as drivers of the magnitude of their role in corporate capital structure decisions.

The second set of survey questions intends to examine investors' level of agreement with the most important capital structure theories. Capital structure is an important consideration for investors. On a scale from one ("capital structure is not at all important") to five ("capital structure is extremely important"), equity, straight bond, and convertible bond investors give respective scores of $3.94,4.26$, and 4.20 . We systematically compare our results with those obtained from Graham and Harvey's (2001) seminal survey analysis questioning corporate chief financial officers (CFOs) on capital structure theories. Our key findings are as follows. Static trade-off factors are deemed important by investors, but in different ways than for corporate managers. More specifically, investors do not consider tax advantages of corporate debt to be important, consistent with the characteristics of Australia's dividend imputation system. However, investors support agency conflicts between managers and shareholders as drivers of corporate capital structure, while corporate managers do not believe agency-driven capital structure explanations to be important (Graham and Harvey, 2001). Consistent with pecking order theory, a sizable proportion of investors expect to revise their firm valuations downward or sell stock in reaction to equity offerings. This result holds especially if there are signals of equity overvaluation, resulting in higher equity-related adverse selection costs. The latter finding contrasts with the results of Graham and Harvey (2001), who do not find evidence for an adverse selection explanation for corporate pecking order behavior. Finally, consistent with these authors, we find strong evidence that market timing and equity dilution concerns drive capital structure decisions.

We also asked respondents about their perceptions of financial constraints. Overall, they consider these constraints relevant for investment decisions. When looking at individual measures of financial constraints, investors seem to perceive the Kaplan-Zingales (KZ) (1997) 
and Whited-Wu (WW) (2006) index components as more important than age and size, which are the components of the Hadlock-Pierce (HP) (2010) index.

Overall, our results suggest that institutional investors are first-order drivers of capital structure decisions, with the strength of their influence depending on a range of firm, investment, and market characteristics.

Our study is, to our knowledge, the first survey analysis to examine capital structure decisions through the eyes of institutional investors. Related to our work, several recent studies examine the impact of institutional investors on corporate finance policies and outcomes. Brav et al. (2008) examine the impact of hedge fund activism on firms' governance and performance, while Appel et al. (2016) and Schmidt and Fahlenbrach (2017) focus on the role of passive investors. More closely related to the topic of capital structure, Chemmanur et al. (2009) and Chemmanur et al. (2010) document the role of institutional investors in seasoned equity offerings and initial public offerings, respectively, and Ivashina and Sun (2011) focus on institutional investors' impact on loan costs. Chang et al. (2018) find an impact of institutional investor horizons on firms' debt-equity choice, amount of equity raised, and debt maturity. These papers all use quantitative methods on archival data, while we use survey analysis. Most relevant to our study, McCahery et al. (2016) conduct a survey on the views of institutional investors on corporate governance issues. Consistent with our results, they find evidence of strong interactions between corporate managers and investors, with 63\% of their 143 respondents stating that they have recently engaged in direct discussions with management. We complement their work by focusing on investors' role in capital structure decisions, which are not covered in their survey questions. Also related to our study, Gompers et al. (2016) survey 79 private equity firms about their valuation, value creation, governance, and capital structure practices. Consistent with our findings, the private equity firms in their study support pecking order and market timing theory. Unlike their survey, our survey respondents include a 
wide range of investors from mutual funds, pension funds, and hedge funds, and we focus on capital structure, rather than on a wide range of corporate finance practices.

The remainder of this paper is structured as follows. The next section describes the methodology. Section 3 outlines the findings regarding investors' stated role in corporate capital structure decisions. Section 4 describes survey evidence regarding investors' support for the three main capital structure theories. Section 5 provides results on investors' views on the importance of financial constraints and relevant measures for such constraints. Section 6 summarizes the main findings and outlines our study's limitations and implications.

\section{Survey design and respondent characteristics}

Based on a review of the capital structure and security issuance literature, we developed a draft survey covering questions on the most salient topics in this literature. These topics include capital structure theories, theories on seasoned equity and bond offerings, the importance and measurement of financial constraints, and investors' views on their own involvement in capital structure decisions. We then circulated this draft for feedback among a group of academics with expertise on capital structure research. After incorporating their detailed feedback, we beta-tested the survey among a number of fund managers whom we asked to complete the draft questionnaire in our presence and who commented on the questions. We incorporated their feedback in the final version of the questionnaire. Based on the beta-testing, we estimated that it would take ten minutes, on average, to complete the survey. The final survey consists of 25 questions, including an open question with three sub-questions. The Appendix of this paper provides the full questionnaire.

We decided to focus our research on the population of Australian institutional investors. The main reason for this choice is the following. Obtaining a sufficiently high response rate is critical for survey analyses and often very hard to achieve (Dillman et al., 2014). Since three 
of the authors of this paper are affiliated with a highly reputable Australian university, we hoped that our geographical proximity with the respondents, as well as the reputation of our university, might increase investors' willingness to answer the survey. We also hoped that the investors would be more willing to spend further time answering open questions for a survey affiliated with a local, well-known university, one that some of them might even have attended.

We started the search for potential respondents by downloading the names of Australianbased mutual funds and pension (or, in Australian terminology, superannuation) funds from Morningstar Direct. We then used the LinkedIn business account of the lead researcher to look up fund managers within these funds. In the next step, we sent an invitation to the fund managers to connect on LinkedIn. Successful connections provided us with the e-mail addresses of the potential respondents. Our data obtained from Morningstar do not cover hedge funds. For that reason, we also sent out invitations to connect to other institutional investors, including hedge fund investors identified from LinkedIn's suggestions based on the recent investor connections that we made. In the final stage, we sent the connected investors an invitation to complete the questionnaire, with a link to it in the e-mail. We made the LinkedIn connections throughout October 2017 and sent out the survey invitations in November 2017. In total, we sent out 1,712 invitations to managers with whom we connected on LinkedIn. These 1,712 managers represent over 500 distinct financial institutions, according to their LinkedIn profiles. We sent reminders to all LinkedIn connections on December 6, 2017. We collected all responses received by January 15, 2018. In some cases, the respondents did not complete the survey. In that case, the link was left open for a week to allow the respondent to do so. After a week, the incomplete survey data were added to the database. As an incentive, we informed potential participants that they could be included in a draw for two cash prizes of 500 AUD each, which they could either receive or donate. We also promised participants an 
advanced view of the results before they were published. Investors were assured anonymity; therefore, we cannot connect individual responses with investor identities.

We received 275 questionnaires, 154 of which were completed. Complete and incomplete subsamples are very similar regarding the respondent characteristics. Specifically, there are no statistically significant differences between the two groups regarding the nature of their financial institutions, assets under management, or stated importance of capital structure for investment decisions. Based on the total number of received questionnaires (275) and the number of invitations sent out $(1,712)$, our response rate is $16.1 \%$. This percentage compares very favorably with the response rate of $4.3 \%$ obtained by McCahery et al. (2016) in their survey on the role of institutional investors in corporate governance. It is also substantially higher than the response rates of the corporate manager surveys of Graham and Harvey (2001) (9\%), Brounen et al. (2004) (5\%), and Bancel and Mittoo (2004) (12\%), but lower than the response rate of the private equity firm survey of Gompers et al. (2016) (50\%). If we only include completed surveys, the response rate is still $9 \%$ (154 out of 1,712). Table 1 includes a description of the respondents.

[Please insert Table 1 here]

Most of the respondents (157, or 93\%) are male. They are spread over different age categories, but only $3 \%$ are in the category of 61 years and older. The respondents almost all have a university education, many with advanced degrees: 70 (41\%) hold a master's degree, $20(12 \%)$ an MBA, and $8(5 \%)$ a PhD. Most respondents work in mutual funds (90, or 33\%). Pension or superannuation funds also account for a substantial share of the respondents $(74$, or 27\%). This is consistent with the documented importance of pension funds in Australia (IMF, 2016), driven by Australia's mandatory pension fund system (Tang, 2016). ${ }^{6}$ Assets under

\footnotetext{
${ }^{6}$ While most empirical studies tend to treat non-bank institutional investors as a homogenous group, Del Guercio and Hawkins (1999) and Woidtke (2002) provide evidence of the monitoring role of pension funds in particular. Chang et al. (2018) argue that pension funds tend to have a longer-term horizon than other institutional investors
} 
management of the parent business vary greatly, with 13 respondents $(5 \%)$ working for a business that manages less than 50 million AUD (approximately 40 million USD) in assets under management and 74 respondents working for a business with over 100 billion AUD (approximately 80 billion USD) in assets under management. Given that we focused our search on Australian investors, it is not surprising that most businesses are headquartered in Australia $(83 \%)$, with the remainder largely incorporated in the U.S. (11\%) or the U.K. (4\%).

To rule out the possibility that most of our respondents come from very few investment institutions, we cross-tabulate the observations by three identifying characteristics: type of institution, assets under management, and headquarter country. In our sample of 275 observations, we find 47 distinct clusters of observations with at least one respondent in each. This finding unambiguously shows that there are respondents from at least 47 institutions represented in the sample. The largest cluster of respondents (26 in total) corresponds to Australian-based mutual funds with between 1 and 10 billion AUD under management. This cluster still only accounts for less than ten percent of the total sample. It is very likely that the actual number of institutions represented in the sample is much larger than 47, but we do not have additional identifying data to further discriminate within the clusters.

We asked respondents what types of securities they typically select. Since some fund managers are responsible for more than one security type, there is some overlap between the different categories. Most managers (156, or almost 64\%) are responsible for selecting stocks, $48(20 \%)$ for selecting straight bonds, and 34 (14\%) for selecting convertible bonds.

We also asked respondents about their role in the decision-making process. We then linked this role to the type of securities for which they are responsible. Table 2 presents the results.

[Please insert Table 2 here]

such as mutual funds. In unreported results, we do not find any meaningful differences between the responses for pension funds and other investors. 
Table 2 indicates that many of our respondents are part of an organization that works with committees or teams. Most are committee members, but some respondents are the sole decision makers or chief investment officers. A few respondents are not actively involved in studying company fundamentals. For example, seven equity investors said that they "don't look at balance sheets," implying that they do not consider firm characteristics. ${ }^{7}$ However, reassuringly, the clear majority of our sample is actively involved in the decision making around the investment process.

\section{Capital supply factors}

Baker (2009) argues that traditional corporate finance studies focus on the corporate demand side. These studies implicitly consider the investor side as a black box with perfectly elastic and competitive demand. However, a growing stream of research focuses on the suppliers of capital rather than on the parties seeking capital. While this stream of literature started as early as 1977 with Miller's (1977) theory on optimal leverage incorporating investor tax preferences, it only gained traction more recently with studies of Faulkender and Petersen (2006), Leary (2009), and Lemmon and Roberts (2010). These authors all argue that capital supply factors should have an impact on capital structure decisions, and provide empirical findings supporting this argument. Fan et al. (2012) also find that preferences of capital suppliers play an important role in explaining firms' capital structure. Some studies document evidence of capital supply-driven convertible bond issuance (Loncarski et al., 2009; Choi et al., 2010; De Jong et al., 2013), and of a strong impact of investor preferences on convertible bond

\footnotetext{
${ }^{7}$ These are possibly passive investors who manage index funds. In fact, some of the e-mails that we received from potential respondents mention they are passive investors. These potential respondents indicated that they did not fill out the survey for exactly this reason.
} 
design (Grundy and Verwijmeren, 2018). To our knowledge, there is no prior survey evidence on the role of the supply side of capital in capital structure decisions. ${ }^{8}$

Table 3 reports our survey findings on institutional investors' perceived role in security issuance and design.

[Please insert Table 3 here]

Our results provide strong evidence that investors perceive themselves as important influencers of corporate security choices. Most respondents believe they play a strong role in security issuance decisions, that is, the choice between equity and debt (mean score 4.06, with $83 \%$ agreeing with this statement). Interestingly, a corresponding statement regarding investors' influence on the amount of capital raised has an equally high score (4.14). This result suggests that security offering amounts could be driven by an interplay between corporate financing needs and investor demand. The respondents also strongly believe that they can influence convertible and straight bond design (mean scores 3.93 and 3.86, respectively). ${ }^{9}$ Mirror questions asking whether respondents believe they have only a minor influence on security issuance and design decisions (added as a cross-check for the previous findings) indicate only low support (mean scores below 3.0, with fewer than $40 \%$ of respondents agreeing with the corresponding statements).

Following Faulkender and Petersen (2006), who use credit ratings as a proxy for bond market access, we also asked about the importance of ratings when considering specific securities. Not surprisingly, credit ratings are deemed more important for firms issuing straight bonds (mean score 2.92) than for firms issuing convertible bonds (mean score 2.57) and

\footnotetext{
${ }^{8}$ In their interview study of corporate executives, Dong et al. (2018) find that companies often issue convertible bonds because there is a large demand from investors, particularly hedge funds. However, the key focus of their study is still on the validity of traditional convertible bond rationales, which all start from the assumption of firmspecific financing costs driving convertible bond financing.

${ }^{9}$ We did not ask a corresponding question for equity offerings, since the design parameters for such offerings are much more limited.
} 
common shares (mean score 2.13). However, credit ratings do not seem to be considered very important overall, because even the score for straight bonds is not very high.

We concluded the analysis of investor influence on capital structure decisions with an open question (consisting of three sub-questions) aimed at gaining more insight into the magnitude and determinants of investor influence. The Appendix provides the full question. The different parts of the question were answered by 96, 99, and 113 respondents, respectively, much higher response rates than we anticipated. The results of the analysis of the open questions are presented in Table 4.

\section{[Please insert Table 4 here]}

The first sub-question asks investors to estimate the magnitude of their impact on capital structure decisions, compared with the magnitude of the impact of firm and macroeconomic characteristics (i.e., determinants traditionally considered in capital structure studies). On average, investors believe that their influence accounts for $45 \%$ of capital structure decisions, with firm and macroeconomic characteristics accounting for the remainder. The answers have quite a large spread, however, with a minimum estimate of $5 \%$ and a maximum of $100 \%$. Some respondents also provided a short justification of their estimate. Again, there is large variation in these arguments. At one end of the spectrum, an investor argues, "Investor influence is very small," while, at the opposite end, we find quotes such as, "[The impact of] investor preference is extremely large in my experience and I don't think it should be. I also, however, think most companies don't allocate capital very well." Most investors argue that the magnitude of their influence depends on a range of factors (which we examine further in the third sub-question): "I think it is a very broad spectrum; some companies would not consider investor preferences at all, but others would give it a strong input."

The second sub-question asks investors how they influence capital structure decisions. Specifically, we want to know whether they engage in direct talks with management or only 
exert indirect influence through interactions with the investment banks involved in security offerings. Approximately one-third of the investors only talk directly with corporate management (31\%), while approximately one-fifth (19\%) only talk with the investment bank and not with the company. Approximately half of the investors use both mechanisms of influence $(47 \%)$. A sizable number of investors (10) argue that the magnitude of their shareholdings in the firm determines their channel of influence. Larger shareholdings are more likely to result in direct influence, while smaller shareholdings are associated with indirect influence through the investment bank. Two investors argue that one way to influence capital structure is to "vote with your feet" and refuse to participate in security offerings with which they do not agree.

The third sub-question examines the determinants of the strength of investors' influence on capital structure decisions. The most important factor cited by investors is firm size (71 of 113 respondents). In particular, they feel they can use stronger influence on smaller firms. Representative quotes include the following: "Smaller are always more open-have less investment bankers chasing them, and they are open and receptive to all ideas" and "Smaller firms; bigger ones are a law unto themselves until they need us." Other important determinants are firm age and the presence of financial constraints or, potentially related, the need for financing and financial difficulties. As one respondent puts it, "Beggars can't be choosers." Several investors also mention firms' security issuance frequency as a determinant, but they diverge on the direction of the impact. Three out of four investors argue that less frequent issuers rely more on their input, while one argues that more frequent issuers might exert more effort to please investors. In addition to firm characteristics, several respondents mention the size of their shareholdings in the firm, as well as the strength of their relation with the firm and their own size as moderators of their influence on capital structure decisions. Finally, capital market conditions and liquidity are mentioned by one investor each. We conclude that the 
magnitude of investors' influence on capital structure decisions seems to be affected by a combination of firm, investor-firm relation, and (to a much lesser extent) market characteristics.

\section{Investors' views on capital structure theories}

Since equity and straight debt constitute the most important sources of financing, there is a vast theoretical and empirical literature on the choice between them. Important theories that explain the choice between equity and debt are static trade-off theory (Kraus and Litzenberger (1983), pecking order theory (Donaldson, 1961; Myers and Majluf, 1984), and market timing theory (Stein, 1996; Baker and Wurgler, 2002).

Static trade-off theory states that firms have optimal debt-equity ratios, determined by trading off the advantages and disadvantages of leverage. The advantages of leverage consist of a reduction in the agency costs of equity and the corporate tax advantage of interest deductibility. The disadvantages of leverage consist of financial distress costs, agency costs of debt, and personal tax expenses that debtholders incur when receiving interest income. Pecking order theory, in turn, argues that, due to the higher adverse selection costs associated with equity issuance, firms will prefer debt to equity financing. They will only issue the most expensive security (equity) when forced to, that is, when financially constrained. Market timing theory posits that managers are able to time the market and issue equity when the firm's stock is overvalued and retire equity when it is undervalued. Table 5 provides the answers to survey questions intended to test investors' support for each of these key theories.

\section{[Please insert Table 5 here]}

We started by asking the respondents how important they find the capital structure (i.e., the amount of debt versus equity) of the underlying company in their decision to invest in individual companies. On a scale from one (not at all important) to five (extremely important) 
equity investors, on average, give a score of 3.94 for this question. Capital structure is even more important for convertible bond investors (4.20) and straight bond investors (4.26). The difference between stock and bond investors is significant at the $10 \%$ level and the difference between stock and convertible bond investors is significant at the $5 \%$ level. ${ }^{10} \mathrm{We}$ conclude that, overall, capital structure is an important consideration for institutional investors.

In the next three sections, we discuss the evidence for each of the three main capital structure theories. We systematically compare our findings with those of Graham and Harvey (2001), who surveyed U.S. CFOs on similar issues. ${ }^{11}$

\subsection{Static trade-off theory}

We asked which factors investors consider when considering the capital structure of a company in which they are investing. Regarding factors related to static trade-off theory, we find that investors are particularly concerned about the company having too much debt to risk financial distress (4.47). Maintaining financial flexibility is also deemed important (3.93), consistent with the survey results of Graham and Harvey (2001). Maximizing the tax deductibility of interest receives the lowest score (2.43). This result is in line with previous survey evidence for Australian corporate treasurers by Faff et al. (2016). It is likely driven by the Australian dividend imputation system. More particularly, corporate taxes paid by Australian companies can be allocated to shareholders by way of imputation credits included in dividends, thereby making the tax deductibility of debt interest payments less attractive (Twite, 2001; Akthar, 2005).

\footnotetext{
${ }^{10}$ Significance levels are not included in the table.

${ }^{11}$ Other surveys in the literature covering capital structure obtain findings similar to those of Graham and Harvey (2001) for other countries than the U.S., e.g. Bancel and Mittoo (2004) and Brounen et al. (2004), (2006) for European firms, and Faff et al. (2016) for Australian firms. We do not separately refer to these surveys in the remainder of this section.
} 
Statement 5 in Q12 tests the benefits of straight debt in controlling agency costs of equity by mitigating excessive managerial spending: "The company having sufficient debt, so as to avoid managers wasting corporate cash on pet projects and perks such as negative net present value acquisitions that increase managerial prestige, large offices, corporate jets, etc." This statement receives a decent amount of support in our survey, with a mean score of 2.94 and $33 \%$ of respondents finding it important. ${ }^{12}$ Graham and Harvey (2001) include the following statement to examine agency costs of equity: "To ensure that upper management works hard and efficiently, we issue sufficient debt to make sure that a large portion of our cash flow is committed to interest payments." That statement is only found to be important by $2 \%$ of the corporate executives participating in their study, with a mean score of only $1.33 .^{13}$

Further corroborating the importance of agency costs in our survey, we obtain even higher scores on questions on the importance of overinvestment (3.41) and underinvestment (3.48) concerns associated with debt financing. Graham and Harvey (2001) do not have direct equivalents for those questions. Only when asking about convertible bond issuance do they assess potential overinvestment concerns, with the following statement: "Protecting bondholders against unfavorable actions by managers and shareholders." This question essentially tests the same risk-shifting/overinvestment agency problem that we examine with our statement 4 for Q12: “The company not having so much debt that management might be tempted to invest in too risky, negative net present value projects (i.e., projects with a small chance of a very high payoff)." ${ }^{14}$ Graham and Harvey (2001) find that only $1 \%$ of companies that seriously considered convertible bonds find this problem to be important, with a mean score of 1.62. That result contrasts with the mean score of 3.41 for our sample mentioned earlier, with $55 \%$ of respondents finding this problem to be important.

\footnotetext{
12 This statement is presented as "limit managerial empire building" in Table 5.

${ }^{13}$ They document a score of 0.33 , but since they use a scale from 0 to 4 instead of 1 to 5 , their score translates into 1.33 on our scale. We have made similar adjustments in the remainder of the text.

${ }^{14}$ This statement is presented as the "risk of overinvestment due to excess debt" in Table 5.
} 
A plausible explanation for the discrepancy between Graham and Harvey's (2001) and our own results on agency costs is that corporate managers are not aware of the potential harmful role of agency costs, and their role in creating these. Alternatively, managers might understand the problem but might be unwilling to deal with it. Our findings, by contrast, show that investors are well aware of the agency costs of equity and debt, and do find them important in judging firms' capital structure.

Finally, our results suggest that investors do not seem to care much about companies having the same debt ratio as their peers, with the corresponding statement receiving a score of 2.56. This finding is in line with Graham and Harvey's (2001) result that peer behavior only seems a minor consideration for firms in setting capital structure.

As an extension to the survey results in Table 5, Table 6 presents the results of ordered logit regressions of the importance of capital structure on the type of investor, the characteristics of the investment institution, and the demographic characteristics of the respondents.

\section{[Please insert Table 6 here]}

The dependent variable is the response to the question, "When deciding to invest, how important is the capital structure?" Respondents were asked to answer the question on a fivepoint Likert scale ranging from one, for not at all important, to five, extremely important. Column (1) of Table 6 presents the base case in which we relate the answers to this question to the type of investor. We find that straight bond investors are significantly more concerned about capital structure than stock investors are. That result is intuitive. Straight bond investors lose out from companies being levered too strongly, while unlike stock investors, they do not benefit from the gains of using too much leverage. Convertible bond and other investors do not find capital structure significantly more important than common stock investors do. In Column (2), we add variables for the type of investment institution. Two remarkable results from this 
analysis are the fact that hedge funds and U.S.-based investors are both less concerned about capital structure than other types of investors are. In Column (3), we add the characteristics of the respondents to the base case. We find that investors with $\mathrm{PhD}$ or master's degrees find capital structure less important than other investors do. Overall, after controlling for various institutional and demographic characteristics, the main result from this table stands that straight bond investors find capital structure significantly more important than stock and other investors do.

\subsection{Pecking order theory}

Table 7 provides the results for our questions aimed at testing the validity of pecking order theory.

[Please insert Table 7 here]

Pecking order theory predicts that risky security offerings will be associated with a negative stock price effect, since they signal that the firm is overvalued. Moreover, the theory predicts that more equity-like security offerings will provoke more negative stock price reactions than debt-like security offerings will, since the former provide a stronger signal of equity overvaluation (Myers and Majluf, 1984). Consistent with the predictions, Table 7 shows that investors are much more likely to revise their valuations downward or sell stock following corporate equity offerings than after straight bond offerings (mean scores of 2.97 versus 2.54 , respectively, the difference being significant at the $1 \%$ level). The score for convertible bond offerings is only slightly lower than that for equity offerings (mean scores of 2.97 versus 2.92 , respectively, the difference being not statistically or economically significant), suggesting that investors perceive convertibles to be very similar to equity. ${ }^{15}$ However, Table 7 also shows that

\footnotetext{
15 This perception confirms the results of Lee et al. (2009), who study the equity-likeness of convertible bonds in different countries. In line with Lewis et al. (2003), they define equity-like convertibles as those that have a probability of conversion above $60 \%$. The probability of conversion of Australian convertibles in their research is $70 \%$, making them highly equity-like, on average.
} 
only approximately one-fourth (27\%) of institutional investors agree or strongly agree that they would revise their opinion on a firm's stock downward if the firm announced an equity offering. This percentage is surprisingly low considering pecking order theory's prediction that equity offerings are associated with a downward stock price revision.

In follow-up yes/no questions, we asked those investors who do revise their valuations based on security offerings to assess the validity of several factors suggested by pecking order theory. In total, $88 \%$ of respondents agree that their valuation revision and/or probability of selling stock following an equity offering announcement would be stronger if there were less information available about the company's value of assets in place. This result is consistent with pecking order theory's prediction that adverse selection costs should be more severe for firms with higher information asymmetry. A revised version of the pecking order theory predicts adverse selection costs to be less severe for firms with valuable growth opportunities (Cooney and Kalay, 1996). In line with this theory, $88 \%$ of the respondents agree with the argument that they would adopt a less negative revaluation following equity offering announcements by companies with valuable growth options. Krasker's (1986) model predicts higher adverse selection costs for larger equity offerings. This prediction also receives strong support from the respondents, with $82 \%$ of the investors agreeing that larger offering sizes would result in larger downward stock price revisions.

Finally, Myers and Majluf (1984) predict higher adverse selection costs for firms with larger amounts of slack capital available, since equity offerings for such firms could send a stronger signal of firm overvaluation. Consistent with this prediction, Bayless and Chaplinsky (1991) find that firms with more slack capital are less likely to issue equity compared with straight bonds, arguably to mitigate equity-related adverse selection costs. In our survey, we find little evidence that firms' slack capital matters in affecting their adverse selection costs. Only slightly more than half $(55 \%)$ of the respondents agree that they would make a smaller 
downward stock price revision for equity issuers with smaller cash reserves (acting as a common proxy for slack capital). We do not find differences in any answers across investor and fund characteristics, except for the fact that the importance of information about assets in place is significantly greater for smaller funds (which, arguably, could have fewer analysts available to tap nonstandard sources for company information) and for non-U.S. funds, while better-educated investors support the importance of slack capital.

Overall, we conclude that, while the overall percentage of respondents making downward stock price revisions or selling shares following risky security offering announcements is lower than expected, other answers are strongly consistent with predictions yielded by pecking order theory. Adverse selection seems to be a strong driver of investor reactions to security offerings. This conclusion differs from that of Graham and Harvey (2001). While they do find evidence of pecking order behavior in CFOs' security choice decisions, CFOs' answers suggest that these pecking order tendencies are not affected by adverse selection concerns. Our results in Table 7 therefore uncover a tension between the determinants of CFOs' external financing choices, and those of investor reactions to these choices.

For completeness, we also asked investors about the importance of equity dilution concerns around equity offering announcements. The survey evidence of Graham and Harvey (2001) strongly supports the notion that earnings per share (EPS) dilution matters for CFOs. Nearly $69 \%$ of the CFOs who seriously consider issuing common equity in their study (strongly) agree with the statement that EPS dilution affects their issuance decision, making this the most important factor affecting common equity offerings. In our survey, we ask about equity dilution, which includes both EPS and control (voting rights) dilution. We find strong evidence that dilution concerns matter. As the last row of Panel A in Table 7 shows, the relevant survey statement receives a mean score of 4.45 , with $90 \%$ of the investors (strongly) agreeing with it. According to standard theory, EPS dilution should not be a concern for investors if the firm 
earns the required return on new equity (Brealey et al., 2012). However, concerns about voting rights are legitimate. Given that we asked about the combination of the two factors, we are unable to separate these two effects, but we do find that CFOs and investors likely hold similar opinions on this issue.

\subsection{Market timing theory}

Table 8 provides the results on market timing theory. Consistent with the key prediction of market timing theory, the survey statement that firms tend to offer equity when equity valuations are high receives very strong support (mean score of 4.07 , with nearly $80 \%$ of respondents (strongly) agreeing). These results mirror those of Graham and Harvey (2001), who find strong support for equity market timing behavior among CFOs.

[Please insert Table 8 here]

Extending the market timing argument to straight bond markets, we obtain the prediction that firms try to time straight bond offerings when economy-wide interest rates are low. Support for this argument is slightly weaker than for the equity market timing argument (mean score of 3.78, with nearly $70 \%$ of respondents (strongly) agreeing). Convertible bond issuers could exhibit both equity and straight bond market timing tendencies, given their hybrid characteristics. Accordingly, investors believe that convertible bond issuers time both equity and bond markets, although the scores are slightly weaker than for the corresponding nonhybrid securities. Investors with stronger educational backgrounds seem to have a stronger belief in the market timing tendencies of convertible bond issuers. This finding could be associated with the fact that they have a better overall understanding of the hybrid design of convertible bonds. In theory, firms could try to time convertible bond offerings when volatility is high, because this might enable them to sell the embedded call option at a higher price. However, our results provide little evidence of the importance of such volatility timing 
behavior as perceived by investors. Overall, our results show that market timing is not only exercised by firms, as found by Graham and Harvey (2001), but is also fully anticipated and likely priced by investors.

\section{Financial constraint theories and measures}

Firms are defined as financially constrained if it is considerably cheaper for them to use internal funds than external funds. There are different ways to measure financial constraints and the literature does not agree which of these variables is the most suitable. Until recently, the $\mathrm{KZ}$ index was very popular as a measure of financial constraints. This index includes the following variables: cash flow to total assets, leverage, dividend to total assets, and cash to total assets. ${ }^{16}$ An alternative for this index is the WW index, which includes some of the same variables as the $\mathrm{KZ}$ index, others that are defined slightly differently, and some new variables. More specifically, the WW index comprises the following variables: cash flow to total assets, a dummy for dividend-paying firms, long-term debt to total assets, the natural logarithm of total assets, the firm's three-digit industry sales growth, and the firm's sales growth. In an empirical study, Hadlock and Pierce (2010) compare the two indexes and conclude that neither is truly suitable for measuring financial constraints. They therefore suggest a new index, the HP index. This index consists of the age and size of the firm, as well as the square of the firm's size.

We asked the respondents whether they find financial constraints important in investing. In addition, we asked them to rate different variables that are included in the different indexes based on their perceived importance as measures of financial constraints. Table 9 provides the results.

\footnotetext{
${ }^{16}$ We only asked about the Baker-Stein-Wurgler (2003) version of the KZ index. The Lamont-Polk-Saá-Requejo (2001) version also includes Tobin's Q.
} 
[Please insert Table 9 here]

Overall, investors find financial constraints to be moderately important. The mean score for this question is 3.51 and slightly more than $52 \%$ of the respondents indicate that they find financial constraints to be important or very important. This result holds for all different types of investors, with U.S.-based investors finding financial constraints to be somewhat less important compared to investors from other countries.

When looking at individual measures of financial constraints, it becomes obvious that the two components of HP index are not deemed very important. The mean score for firm size is 2.94, while age receives the lowest score of all financial constraints, 2.05. In addition, these scores do not seem to differ much across types of investors. The scores for the individual components of the $\mathrm{KZ}$ and $\mathrm{WW}$ indexes are much higher. Leverage and cash flow to total assets, which are part of both indexes, both score very high, with mean scores of, respectively, 4.18 and 4.01. Again, there is not much variation between different categories of investors. Scores for other components of these two indexes also tend to be higher than the scores for the two individual components of the HP index. ${ }^{17}$ Overall, our results suggest that investors measure financial constraints with the components of the $\mathrm{KZ}$ and $\mathrm{WW}$ indexes rather than the HP index. One potential explanation for this finding is that the components of the former indexes may be more visible and easier to understand for investors than the components of the latter index.

\section{Summary and conclusions}

The seminal paper of Graham and Harvey (2001), in which they survey CFOs on various corporate finance topics including capital structure, paved the way for the acceptance of

\footnotetext{
17 The only exception is the ratio of dividends to total assets, which scores lower than firm size but higher than age.
} 
questionnaires as a well-respected research instrument in finance. The authors' U.S.-based survey was followed up by survey analyses of European CFOs (e.g., Brounen et al., 2004, 2006; Bancel and Mittoo, 2004) and Australian corporate treasurers (Faff et al., 2016). However, until now, nobody had asked institutional investors what they think about the capital structure decisions of the companies in which they invest or are at least contemplating investing, as well as their impact on these decisions. This is an important gap in the literature, given the increasing role of institutional investors as corporate capital providers around the world (Ferreira and Matos, 2008). We fill this gap in the literature by surveying 275 Australian institutional investors on this topic.

We first examine the importance of the supply side of the market as a driver of capital structure decisions. We find that more than $82 \%$ of the respondents believe that they have a strong influence on the security issuance choice of the firms in which they invest or are considering investing, and more than $84 \%$ believe that they have a strong influence on the amount of financing that these firms raise. Investors influence capital structure decisions both directly through talks with management, and indirectly through talks with the investment banks assisting with securities issuance. Overall, our results highlight the strong role of institutional investors as first-order drivers of firms' capital structure decisions. Investors, furthermore, mention several moderators affecting the strength of their potential impact on firms' decisions, including firm characteristics such as age and size, as well as characteristics of the investorfirm relation.

We find that, among equity, convertible bond, and straight bond investors, more than $75 \%$, $83 \%$, and $84 \%$, respectively, indicate that they find capital structure important when making the decision to invest in a particular company. With regard to the validity of capital structure theories governing firms' decisions, Graham and Harvey (2001) find that CFOs do not find agency problems to be important. We find the opposite for investors: more than $50 \%$ of our 
respondents consider agency problems of overinvestment and underinvestment to be important. One explanation for this discrepancy is that managers are unaware of the impact of agency costs on their capital structure decisions. We furthermore find support for adverse selection costs-driven pecking order, market timing, and equity dilution explanations for capital structure. These results are mostly consistent with those of Graham and Harvey (2001), although these authors do not find that pecking order behavior results from adverse selection costs.

An obvious possible follow-up to this research would be to conduct a similar study for the U.S. Given the dividend imputation system that is used in Australia and not in the U.S., a study for the U.S. may lead to some different findings on the importance of the tax deductibility of interest for corporate tax purposes. However, for the remaining part we would not expect many differences, since the institutional setting for both countries is very similar. Of course, our survey could be extended to other countries than the U.S. as well.

Our survey measures investors' stated influence and views on corporate capital structure (theories). These stated opinions are subjective in nature, and may differ from investors' actual role and views. For example, investors may want to provide inflated estimates of their own importance in deciding firms' capital structure. Like other surveys, we hope that the anonymous nature of our survey has encouraged investors to respond honestly to our questions, thereby reducing potential biases in our findings (Gompers et al., 2016). Overall, we expect that our results will be useful in future empirical research modeling the impact of investor preferences and capital supply on corporate finance decisions. 


\section{References}

Akhtar, S. "The Determinants of Capital Structure for Australian Multinational and Domestic Corporations." Australian Journal of Management, 30 (2005), 321-341.

Appel, I.R., T.A. Gormley, and D.B. Keim. "Passive Investors, Not Passive Owners." Journal of Financial Economics, 121 (2016), 111-141.

Baker, M. "Capital Market-Driven Corporate Finance." Annual Review of Financial Economics, 1 (2009), 1-41.

Baker, M., J. Stein, and J. Wurgler. "When Does the Market Matter? Stock Prices and the Investment of Equity-Dependent Firms." Journal of Financial Economics, 118 (2003), 9691005.

Baker, M., and J. Wurgler. "Market Timing and Capital Structure.” Journal of Finance, 57 (2002), $1-32$.

Bancel, F., and U. Mittoo. "Cross-Country Determinants of Capital Structure Choice: A Survey of European Firms.” Financial Management, 33 (2004), 103-132.

Bayless, M., and S. Chaplinsky. "Expectations of Security Type and the Information Content of Debt and Equity Offers.” Journal of Financial Intermediation, 1 (1991), 195-214.

Brav, A., W. Jiang, F. Partnoy, and R. Thomas. "Hedge Fund Activism, Corporate Governance, and Firm Performance.” Journal of Finance, 63 (2008), 1729-1775.

Brealey, R. A., S. C. Myers, F. Allen, and P. Mohanty. Principles of Corporate Finance. New York: Tata McGraw-Hill Education (2012).

Brounen, D., A. De Jong, and C. G. Koedijk. "Corporate Financing in Europe: Confronting Theory with Practice.” Financial Management, 33 (2004), 71-101.

Brounen, D., A. De Jong, and C. G. Koedijk. "Capital Structure Policies in Europe: Survey Evidence.” Journal of Banking and Finance, 30 (2006), 1409-1442.

Chang, X., Y. Chen, K. Fu, and E. Yang, "Institutional Investor Horizons, Information Environment, and Firm Financing Decisions", Working Paper (2018).

Chemmanur, T.J., S. He, and G. Hu. "The Role of Institutional Investors in Seasoned Equity Offerings.” Journal of Financial Economics, 94 (2009), 384-411.

Chemmanur, T.J., G. Hu, and J. Huang. "The role of Institutional Investors in Initial Public Offerings." The Review of Financial Studies, 23 (2010), 4496-4540.

Choi, D., M. Getmansky, B. J. Henderson, and H. Tookes. "Convertible Bond Arbitrageurs as Suppliers of Capital.” Review of Financial Studies, 23 (2010), 2492-2522.

Cooney, J. W., and A. Kalay. "Positive Information from Equity Issue Announcements." Journal of Financial Economics, 33 (1996), 149-172.

DeAngelo, H., L. DeAngelo, and R. M. Stulz. "Seasoned Equity Offerings, Market Timing, and the Corporate Life Cycle." Journal of Financial Economics, 95 (2010), 275-295.

Degeorge, F., Y. Ding, T. Jeanjean, and H. Stolowy. "Analyst Coverage, Earnings Management and Financial Development: An International Study." Journal of Accounting and Public Policy, 32 (2013), 1-25. 
De Jong, A., E. Duca, and M. Dutordoir. "Do Convertible Bond Issuers Cater to Investor Demand?" Financial Management, 42 (2013), 41-78.

De Jong, A., R. Kabir, and T. T. Nguyen. "Capital Structure around the World: The Roles of Firm- and Country-Specific Determinants." Journal of Banking and Finance, 32 (2008), 1954-1969.

De Jong, A., and Verwijmeren, P. "To Have a Target Debt Ratio or Not: What Difference Does It Make?”, Applied Financial Economics, 20 (2010), 219-226.

Del Guercio, D., and Hawkins, J. "The Motivation and Impact of Pension Fund Activism." Journal of Financial Economics, 52 (1999), 293-340.

Dillman, D. A., J. D. Smyth, and L. M. Christian. Internet, Phone, Mail, and Mixed-Mode Surveys: The Tailored Design Method. John Wiley \& Sons (2014), Hoboken, New Jersey.

Donaldson, G. Corporate Debt Capacity: A Study of Corporate Debt Policy and the Determination of Corporate Debt Capacity. Harvard Business School, Division of Research, Harvard University (1961), Boston, Massachusetts.

Dong, M., M. Dutordoir, and C. Veld. "Why Do Firms Issue Convertible Bonds?" Critical Finance Review 7 (2018), 111-164.

Dong, M., I. Loncarski, J. Ter Horst, and C. Veld. "What Drives Security Issuance Decisions? Market Timing, Pecking Order, or Both.” Financial Management, 41 (2012), 637-663.

Faff, R. W., S. Gray, and K. J. K. Tan. "A Contemporary View of Corporate Finance Theory, Empirical Evidence and Practice.” Australian Journal of Management, 41 (2016), 662-686.

Fama, E. F., and K. R. French. "Financing Decisions: Who Issues Stock?" Journal of Financial Economics, 76 (2005), 549-582.

Fan, J. P. H., S. Titman, and G. Twite. "An International Comparison of Capital Structure and Debt Maturity Choices.” Journal of Financial and Quantitative Analysis, 47 (2012), 23-56.

Faulkender, M., and M. A. Petersen. "Does the Source of Capital Affect Capital Structure?" Review of Financial Studies, 19 (2006), 45-79.

Ferreira, M.A., and P. Matos. "The Colors of Investors' Money: The Role of Institutional Investors around the World." Journal of Financial Economics, 88 (2008), 499-533.

Frank, M. Z., and V. K. Goyal. "Testing the Pecking Order Theory of Capital Structure.” Journal of Financial Economics, 67 (2003), 217-248.

Gomes, A., and G. Phillips. "Why Do Public Firms Issue Private and Public Securities?” Journal of Financial Intermediation, 21 (2012), 619-658.

Gompers, P., S.N. Kaplan, and V. Mukharlyamov. "What Do Private Equity Firms Say They Do?" Journal of Financial Economics 121 (2016), 449-476.

Graham, J. R., and C. R. Harvey. "The Theory and Practice of Corporate Finance: Evidence from the Field." Journal of Financial Economics, 60 (2001), 187-243.

Grundy, B.D. and P. Verwijmeren. "The Buyers' Perspective on Security Design: Hedge Funds and Convertible Bond Call Provisions.” Journal of Financial Economics, 127 (2018), 77 93. 
Hadlock, C. J. and J. R. Pierce. "New Evidence on Measuring Financial Constraints: Moving beyond the KZ Index." Review of Financial Studies, 23 (2010) 1909-1940.

Hovakimian, A., T. Opler, and S. Titman. "The Debt-Equity Choice.” Journal of Financial and Quantitative Analysis, 36 (2001), 1-24.

International Monetary Fund (IMF). "Global Financial Stability Report", available from www.imf.org (October, 2016). Last accessed January 7, 2019.

Ivashina, V., and Z. Sun. "Institutional Demand Pressure and the Cost of Corporate Loans." Journal of Financial Economics, 99 (2011), 500-522.

Jung, K., Y.-C. Kim, and R. M. Stulz. “Timing, Investment Opportunities, Managerial Discretion, and the Security Issuance Decision.” Journal of Financial Economics, 42 (1996), 159-185.

Kaplan, S. N., and L. Zingales. "Do Investment-Cash Flow Sensitivities Provide Useful Measures of Financing Constraints.” Quarterly Journal of Economics, 112 (1997), 169-215.

Krasker, W. S. "Stock Price Movements in Response to Stock Issues under Asymmetric Information." Journal of Finance, 41 (1986), 93-105.

Kraus, A., and R. H. Litzenberger. "A State-Preference Model of Optimal Financial Leverage," Journal of Finance, 28 (1983), 911-922.

Lamont, O., C. Polk, and J. Saá-Requejo. "Financial Constraints and Stock Returns." Review of Financial Studies, 14 (2001), 529-554.

Leary, M. T. "Bank Loan Supply, Lender Choice and Corporate Capital Structures." Journal of Finance, 64 (2009), 1143-1185.

Leary, M., and M. R. Roberts. "Do Firms Rebalance Their Capital Structures?" Journal of Finance, 60 (2005), 2575-2619.

Lee, C.-F., L. W. Lee, and G. H.-H. Yeo. "Investor Protection and Convertible Debt Design." Journal of Banking and Finance, 33 (2009), 985-995.

Lemmon, M. L., and M. Roberts. "The Response of Corporate Financing and Investment to Changes in the Supply of Credit." Journal of Financial and Quantitative Analysis, 45 (2010), 555-587.

Lewis, C. M., R. J. Rogalski, and J. K. Seward. "Industry Conditions, Growth Opportunities and Market Reactions to Convertible Debt Financing Decisions." Journal of Banking and Finance, 27 (2003), 153-181.

Loncarski, I., J. Ter Horst, and C. Veld. "The Rise and Demise of the Convertible Arbitrage Strategy.” Financial Analysts Journal, 65 (2009) (September-October), 35-50.

McCahery, J. A., Z. Sautner, and L. T. Starks. "Behind the Scenes: The Corporate Governance Preferences of Institutional Investors.” Journal of Finance, 71 (2016), 2905-2932.

Miller, M.H. "Debt and Taxes." Journal of Finance, 32 (1977): 261-275.

Myers, M., and N. S. Majluf. "Corporate Financing and Investment Decisions When Firms Have Information that Investors Do Not Have." Journal of Financial Economics, 13 (1984), 187-221. 
Pattenden, K. "Capital Structure Decisions under Classical and Imputation Tax Systems: A Natural Test for Tax Effects in Australia.” Australian Journal of Management, 31 (2006), 67-92.

Schmidt, C. and R. Fahlenbrach. "Do Exogenous Changes in Passive Institutional Ownership Affect Corporate Governance and Firm Value?" Journal of Financial Economics, 124 (2017), 285-306.

Shyam-Sunder, L., and S. C. Myers. "Testing Static Tradeoff against Pecking Order Models of Capital Structure.” Journal of Financial Economics, 51 (1999), 219-244.

Stein, J. "Rational Capital Budgeting in an Irrational World." Journal of Business, 69 (1996), $429-455$.

Tang, E. "Australia Has the Third Largest Pension Fund Assets in the World", available from www.austrade.gov.au (July, 2016). Last accessed January 7, 2019.

Twite, G. "Capital Structure Choices and taxes: Evidence from the Australian Dividend Imputation Tax System.” International Review of Finance, 2 (2001), 217-234.

Whited, T., and G. Wu. "Financial Constraints Risk." Review of Financial Studies, 19 (2006), 531-559.

Woidtke, T. "Agents Watching Agents?: Evidence from Pension Fund Ownership and Firm Value." Journal of Financial Economics, 63 (2002), 99-131.

Zhou, Q., K. J. K. Tan, R. Faff, and Y. Zhou. "Deviation from Target Capital Structure, Cost of Equity and Speed of Adjustment." Journal of Corporate Finance, 39 (2016), 99-120. 


\section{Table 1. Respondent characteristics}

This table presents the breakdown of the respondents by their demographic and employer characteristics.

\begin{tabular}{|c|c|c|c|}
\hline \multicolumn{2}{|c|}{ Category } & $\begin{array}{l}\text { Number of } \\
\text { respondents }\end{array}$ & $\begin{array}{c}\text { Percentage of } \\
\text { respondents } \\
\end{array}$ \\
\hline \multicolumn{4}{|c|}{ Gender } \\
\hline - & Male & 157 & 92.9 \\
\hline- & Female & 10 & 5.9 \\
\hline- & Transgender & 1 & 0.6 \\
\hline- & Choose not to disclose & 1 & 0.6 \\
\hline Total & & 169 & 100 \\
\hline \multicolumn{4}{|c|}{ Age category } \\
\hline- & Younger than 30 & 30 & 17.8 \\
\hline- & 31 to 40 & 65 & 38.5 \\
\hline- & 41 to 50 & 39 & 23.1 \\
\hline- & 51 to 60 & 29 & 17.2 \\
\hline- & 61 or older & 5 & 3.0 \\
\hline- & Choose not to disclose & 1 & 0.6 \\
\hline Total & & 169 & 100 \\
\hline \multicolumn{4}{|c|}{ Education } \\
\hline- & $\mathrm{PhD}$ & 8 & 4.7 \\
\hline- & MBA & 20 & 11.8 \\
\hline- & Master's & 70 & 41.4 \\
\hline- & Bachelor & 66 & 39.1 \\
\hline- & No university education & 4 & 2.4 \\
\hline- & Choose not to disclose & 1 & 0.6 \\
\hline Total & & 169 & 100 \\
\hline \multicolumn{4}{|c|}{ Type of investor } \\
\hline- & Mutual fund & 90 & 32.7 \\
\hline- & Superannuation fund & 74 & 26.9 \\
\hline- & Hedge fund & 23 & 8.4 \\
\hline- & Insurance company & 8 & 2.9 \\
\hline- & Pension fund & 4 & 1.5 \\
\hline- & Other & 76 & 27.6 \\
\hline Total & & 275 & 100 \\
\hline \multicolumn{4}{|c|}{ Assets under management of (parent) business (millions AUD) } \\
\hline- & Less than 50 & 13 & 4.8 \\
\hline- & 50 to 500 & 31 & 11.4 \\
\hline- & 500 to 1000 & 16 & 5.9 \\
\hline- & 1,000 to 10,000 & 81 & 29.7 \\
\hline- & 10,000 to 100,000 & 58 & 21.3 \\
\hline- & Over 100,000 & 74 & 27.1 \\
\hline Total & & 273 & 100 \\
\hline \multicolumn{4}{|c|}{ Country of incorporation } \\
\hline- & Australia & 224 & 82.7 \\
\hline- & U.S. & 31 & 11.4 \\
\hline- & U.K. & 10 & 3.7 \\
\hline - & Other & 6 & 2.2 \\
\hline Total & & 271 & 100 \\
\hline
\end{tabular}




\begin{tabular}{|c|c|c|c|}
\hline \multicolumn{4}{|c|}{ Responsible for selection of } \\
\hline- & Stocks & 156 & 63.9 \\
\hline- & Corporate straight bonds & 48 & 19.7 \\
\hline- & Money market investments & 44 & 18.0 \\
\hline- & Government bonds & 38 & 15.6 \\
\hline- & Convertible bonds & 34 & 13.9 \\
\hline- & Other & 79 & 32.4 \\
\hline Total & & 244 & 100 \\
\hline
\end{tabular}




\section{Table 2. Respondents' role in decision-making processes}

This table provides an overview of survey respondents' role in investment processes in their organization. The results for respondents responsible for selecting stocks, convertible, and straight bonds are presented separately.

\begin{tabular}{lccc}
\hline $\begin{array}{l}\text { Role in investment } \\
\text { process }\end{array}$ & Stocks & Convertible bonds & Straight bonds \\
\hline Investment committee & 71 & 17 & 24 \\
member & 20 & 3 & 3 \\
Sole decision maker & 17 & 5 & 6 \\
Chief investment officer & 7 & 1 & 0 \\
Nobody looks at balance & & & 7 \\
sheets/only go to annual & 29 & 4 & 40 \\
meetings & 144 & 30 & \\
Other & & & \\
Total & & & \\
\hline
\end{tabular}




\section{Table 3. Survey responses on the role of investors in capital structure decisions}

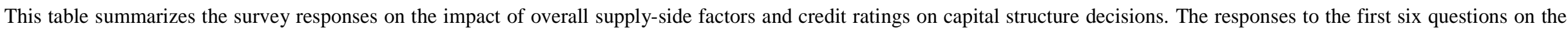

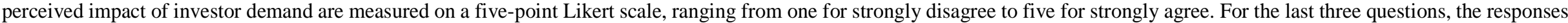

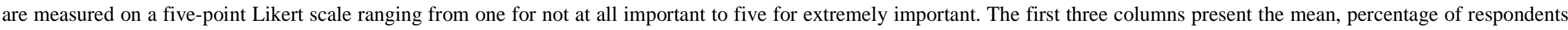

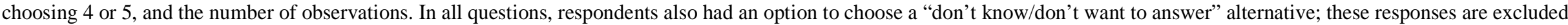

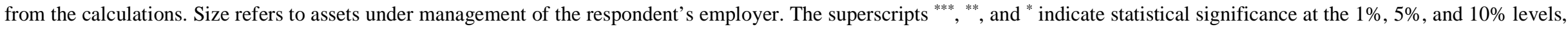
respectively, in two-tailed $t$-tests for the difference of means between every two subgroups of respondents.

\begin{tabular}{|c|c|c|c|c|c|c|c|c|c|c|c|c|c|c|c|}
\hline & \multicolumn{3}{|c|}{ All } & \multicolumn{2}{|c|}{ Age } & \multicolumn{2}{|c|}{ Gender } & \multicolumn{2}{|c|}{ Size } & \multicolumn{2}{|c|}{ Education } & \multicolumn{2}{|c|}{ Country } & \multicolumn{2}{|c|}{ Type of fund } \\
\hline & Mean & $\begin{array}{c}\% 4 \\
\text { and } 5\end{array}$ & $N$ & $\begin{array}{l}40 \text { and } \\
\text { under }\end{array}$ & $\begin{array}{l}41 \text { and } \\
\text { over }\end{array}$ & Male & Other & $\begin{array}{l}\text { Under } \\
10 \text { bn } \\
\text { AUD }\end{array}$ & $\begin{array}{l}\text { Over } \\
10 \text { bn } \\
\text { AUD }\end{array}$ & $\begin{array}{l}\mathrm{PhD} \\
\text { or } \\
\mathrm{MSc}\end{array}$ & Other & US & Other & $\begin{array}{l}\text { Hedge } \\
\text { fund }\end{array}$ & Other \\
\hline \multicolumn{16}{|l|}{ Investor demand } \\
\hline $\begin{array}{l}\text { has a strong influence on } \\
\text { firms' choice of what security } \\
\text { type to issue }\end{array}$ & 4.06 & 82.63 & 167 & 4.08 & 4.06 & 4.09 & 3.73 & 4.11 & 4.00 & 4.14 & 4.01 & 4.13 & 4.05 & 3.81 & 4.09 \\
\hline $\begin{array}{l}\text { - has a strong influence on the } \\
\text { amount of financing that firms } \\
\text { raise in their security offerings }\end{array}$ & 4.14 & 84.02 & 169 & 4.16 & 4.10 & 4.15 & 3.90 & 4.15 & 4.15 & 4.07 & 4.18 & 3.81 & 4.17 & 3.88 & 4.17 \\
\hline $\begin{array}{l}\text { has a strong influence on the } \\
\text { design of convertible bonds }\end{array}$ & 3.93 & 73.47 & 147 & 3.93 & 3.91 & $3.98^{* *}$ & 3.30 & $4.06^{*}$ & 3.77 & 3.91 & 3.93 & 3.71 & 3.96 & 3.85 & 3.94 \\
\hline $\begin{array}{l}\text { has a strong influence on the } \\
\text { design of straight bonds }\end{array}$ & 3.86 & 72.85 & 151 & 3.85 & 3.89 & 3.87 & 3.82 & 3.90 & 3.82 & 3.74 & 3.97 & $3.43^{*}$ & 3.91 & 3.64 & 3.88 \\
\hline $\begin{array}{l}\text { - is not of great influence in } \\
\text { security issuance decisions }\end{array}$ & 2.99 & 38.69 & 168 & 2.84 & 3.13 & 2.96 & 3.18 & 2.87 & 3.13 & 3.07 & 2.91 & 3.00 & 3.00 & 3.13 & 2.98 \\
\hline $\begin{array}{l}\text { - } \begin{array}{l}\text { is not of great influence in } \\
\text { security design decisions }\end{array} \\
\end{array}$ & 2.96 & 38.32 & 167 & 2.88 & 3.01 & 2.95 & 3.00 & $2.81^{* *}$ & 3.17 & 3.05 & 2.87 & 3.06 & 2.95 & 3.13 & 2.95 \\
\hline \multicolumn{16}{|c|}{$\begin{array}{l}\text { Importance of a credit rating when considering the } \\
\text { following securities: }\end{array}$} \\
\hline - $\quad$ Common shares & 2.13 & 14.37 & 167 & 2.10 & 2.16 & $2.02^{* * *}$ & 3.73 & $1.98^{*}$ & 2.35 & $2.40^{* *}$ & 1.92 & 2.13 & 2.13 & 2.00 & 2.15 \\
\hline - Convertible bonds & 2.57 & 27.51 & 149 & 2.59 & 2.46 & $2.46^{* *}$ & 3.45 & 2.42 & 2.77 & $2.82^{* *}$ & 2.29 & 2.54 & 2.58 & 2.12 & 2.63 \\
\hline - $\quad$ Straight bonds & 2.92 & 38.46 & 156 & 2.88 & 2.87 & 2.83 & 3.55 & $2.73^{*}$ & 3.13 & $3.09^{*}$ & 2.69 & 2.86 & 2.93 & 2.44 & 2.97 \\
\hline
\end{tabular}




\section{Table 4. Role of institutional investors in capital structure decisions}

This table summarizes investors' responses on open questions intended to further examine their impact on capital structure decisions. Panel A provides the results for a question asking respondents to quantify what portion of capital structure decisions they account for (with firm and macroeconomic characteristics accounting for the remainder). Panel B documents the channel(s) of influence that investors use to affect capital structure decisions. Panel C gives an overview of the determinants of the strength of investors' impact on capital structure decisions, as mentioned in investors' answers to the related open question. The Appendix provides the full open questions. $N$ denotes the number of responses.

Panel A : Percentage estimate of the magnitude of the impact of investor preferences on capital structure decisions, relative to the impact of firm and macroeconomic characteristics

\begin{tabular}{cccccc}
\hline Mean & Median & Minimum & Maximum & St. deviation & $N$ \\
\hline $44.69 \%$ & $45 \%$ & $5 \%$ & $100 \%$ & $26.59 \%$ & 96 \\
\hline
\end{tabular}

Panel B : Channels of investor influence on capital structure decisions

\begin{tabular}{lrc}
\hline Channel & Number & Percentage \\
\hline Direct influence through talks with firm management & 31 & $31.31 \%$ \\
Indirect influence through investment bank only & 19 & $19.19 \%$ \\
Both direct and indirect influence & 47 & $47.47 \%$ \\
No influence at all & 2 & $2.02 \%$ \\
$N$ & 99 & $100 \%$ \\
\hline
\end{tabular}

Panel C : Determinants of the degree of investor influence on capital structure decisions

\begin{tabular}{lc}
\hline Firm characteristics & Number \\
\hline Size & 71 \\
Age & 33 \\
Financial constraints & 29 \\
Management team or board characteristics & 7 \\
Financial difficulties & 7 \\
Need for funding & 5 \\
Issuance frequency & 4 \\
Growth & 3 \\
Sector & 3 \\
Private & 2 \\
Quality & 2 \\
Risk & 1 \\
Asymmetric information & 1 \\
\hline Investor characteristics & \\
\hline Shareholdings in firm & \\
Strength of relationship with firm & 5 \\
Size & 3 \\
\hline Market characteristics & 2 \\
\hline Lapital market conditions & 113 \\
\hline
\end{tabular}




\section{Table 5. Institutional investors' view on static trade-off theory}

This table summarizes the survey responses on the importance of static trade-off capital structure determinants for institutional investors. Responses are measured on a fivepoint Likert scale ranging from one for not at all important to five for extremely important. The first three columns present the mean, the percentage of respondents ranking each factor at 4 or 5, and the number of observations. In questions regarding separate factors affecting capital structure, the respondents also had an opportunity to choose the “don't know/don't want to answer" alternative; these responses are excluded from the calculations. We mention the responses by order of importance, which does not necessarily correspond to the order of the statements in the survey. Size refers to assets under management of the respondent's employer. The superscripts ${ }^{* * *}$, ${ }^{* *}$, and ${ }^{*}$ indicate statistical significance at the $1 \%, 5 \%$, and $10 \%$ levels, respectively, in two-tailed $t$-tests for the difference of means between every two subgroups of respondents.

\begin{tabular}{|c|c|c|c|c|c|c|c|c|c|c|c|c|c|c|c|}
\hline & \multicolumn{3}{|c|}{ All } & \multicolumn{2}{|c|}{ Age } & \multicolumn{2}{|c|}{ Gender } & \multicolumn{2}{|c|}{ Size } & \multicolumn{2}{|c|}{ Education } & \multicolumn{2}{|c|}{ Country } & \multicolumn{2}{|c|}{ Type of fund } \\
\hline & Mean & $\begin{array}{c}\% 4 \\
\text { and } 5\end{array}$ & $N$ & $\begin{array}{c}40 \text { and } \\
\text { under }\end{array}$ & $\begin{array}{c}41 \text { and } \\
\text { over }\end{array}$ & Male & Other & $\begin{array}{l}\text { Under } \\
10 \text { bn } \\
\text { AUD }\end{array}$ & $\begin{array}{l}\text { Over } \\
10 \text { bn } \\
\text { AUD }\end{array}$ & $\begin{array}{c}\text { PhD or } \\
\text { MSc }\end{array}$ & Other & U.S. & Other & $\begin{array}{l}\text { Hedge } \\
\text { fund }\end{array}$ & Other \\
\hline $\begin{array}{l}\text { When deciding to invest, how } \\
\text { important is capital structure? }\end{array}$ & & & & & & & & & & & & & & & \\
\hline - Common stock investors & 3.94 & 75.5 & 143 & 4.08 & 3.91 & 4.02 & 3.50 & 3.91 & 3.98 & $3.80^{*}$ & 4.15 & $3.25^{* *}$ & 3.98 & $3.47^{* *}$ & 4.01 \\
\hline - Convertible bond investors & 4.20 & 83.3 & 30 & $4.71^{* *}$ & 3.82 & 4.20 & 3.50 & $4.04^{*}$ & 4.71 & 4.14 & 4.18 & $\mathrm{na}^{\mathrm{a}}$ & na & 4.17 & 4.21 \\
\hline - Straight bond investors & 4.26 & 84.6 & 39 & 4.14 & 4.43 & 4.24 & 4.50 & 4.35 & 4.16 & $4.00^{*}$ & 4.57 & 4.00 & 4.27 & $3.40^{* * *}$ & 4.38 \\
\hline - Others & 3.71 & 72.3 & 65 & 3.92 & 3.80 & 3.82 & 4.17 & 3.87 & 3.62 & $3.68^{*}$ & 4.20 & 3.27 & 3.80 & 4.00 & 3.70 \\
\hline $\begin{array}{l}\text { Separate factors affecting capital } \\
\text { structure: }\end{array}$ & & & & & & & & & & & & & & & \\
\hline $\begin{array}{l}\text { - Not having too much debt to } \\
\text { risk financial distress }\end{array}$ & 4.47 & 89.69 & 194 & 4.43 & 4.44 & 4.46 & 4.09 & 4.53 & 4.41 & $4.25^{* *}$ & 4.60 & $3.94^{* *}$ & 4.53 & 4.41 & 4.48 \\
\hline $\begin{array}{l}\text { - Maintaining financial } \\
\text { flexibility }\end{array}$ & 3.93 & 74.48 & 192 & 3.99 & 3.89 & 3.95 & 3.80 & 3.96 & 3.88 & 3.82 & 4.05 & 3.63 & 3.95 & 3.59 & 3.96 \\
\hline $\begin{array}{l}\text { - Losing customers/suppliers } \\
\text { due to excess debt }\end{array}$ & 3.65 & 65.11 & 192 & 3.68 & 3.48 & 3.59 & 3.70 & 3.72 & 3.56 & $3.30^{* * * *}$ & 3.86 & 3.33 & 3.68 & 3.38 & 3.68 \\
\hline $\begin{array}{l}\text { - Risk of underinvestment due } \\
\text { to excess debt }\end{array}$ & 3.48 & 53.88 & 193 & 3.48 & 3.36 & 3.42 & 3.64 & 3.36 & 3.56 & 3.29 & 3.55 & $3.00^{*}$ & 3.53 & 3.35 & 3.49 \\
\hline $\begin{array}{l}\text { - Risk of overinvestment due } \\
\text { to excess debt }\end{array}$ & 3.41 & 55.37 & 186 & 3.40 & 3.35 & 3.36 & 3.64 & 3.51 & 3.28 & 3.25 & 3.48 & 3.06 & 3.46 & 3.50 & 3.41 \\
\hline $\begin{array}{l}\text { - Limit managerial empire } \\
\text { building }\end{array}$ & 2.94 & 33.34 & 192 & $2.73^{*}$ & 3.07 & 2.85 & 3.30 & 2.94 & 2.94 & 2.86 & 2.88 & 2.69 & 2.98 & 2.76 & 2.96 \\
\hline - $\quad$ Same debt ratio as peers & 2.56 & 17.44 & 195 & 2.59 & 2.53 & 2.53 & 3.00 & $2.45^{*}$ & 2.71 & 2.64 & 2.48 & 2.76 & 2.54 & 2.29 & 2.58 \\
\hline $\begin{array}{l}\text { - } \begin{array}{l}\text { Maximizing interest tax } \\
\text { deductibility }\end{array}\end{array}$ & 2.43 & 13.09 & 191 & 2.47 & 2.33 & 2.38 & 2.80 & 2.33 & 2.57 & 2.51 & 2.31 & 2.50 & 2.43 & 2.06 & 2.47 \\
\hline
\end{tabular}

${ }^{a}$ Our sample does not include U.S. convertible bond investors. 


\section{Table 6. Determinants of institutional investors' perceived importance of capital structure}

This table reports the results of ordered logit regressions of the importance of capital structure on the type of investor, the characteristics of the investment institution, and the demographic characteristics of the respondents. The dependent variable is the response to the question, "When deciding to invest, how important is the capital structure?" measured on a five-point Likert scale ranging from one for not at all important to five for extremely important. Common stock investor is the omitted category. Large investor is a dummy variable equal to one when assets under management of the respondent's employer are larger than $\$ 10$ billion, and zero otherwise. $z$-statistics, based on robust standard errors clustered by respondent, are in parentheses. The superscripts ${ }^{* * *},{ }^{* *}$, and ${ }^{*}$ indicate statistical significance at the $1 \%, 5 \%$, and $10 \%$ levels, respectively.

\begin{tabular}{|c|c|c|c|}
\hline \multirow[t]{2}{*}{ Variable } & Type of investor & Investment institution & $\begin{array}{c}\text { Respondent } \\
\text { characteristics }\end{array}$ \\
\hline & $(1)$ & (2) & (3) \\
\hline Convertible bond investor & $\begin{array}{c}0.51 \\
(1.47)\end{array}$ & $\begin{array}{c}0.51 \\
(1.42)\end{array}$ & $\begin{array}{c}0.31 \\
(0.70)\end{array}$ \\
\hline Straight bond investor & $\begin{array}{l}0.65^{* *} \\
(2.09)\end{array}$ & $\begin{array}{l}0.69^{* * *} \\
(2.18)\end{array}$ & $\begin{array}{c}0.73^{*} \\
(1.74)\end{array}$ \\
\hline Other investor & $\begin{array}{l}-0.35 \\
(-1.27)\end{array}$ & $\begin{array}{l}-0.38 \\
(-1.36)\end{array}$ & $\begin{array}{l}-0.11 \\
(-0.30)\end{array}$ \\
\hline Large investor & & $\begin{array}{c}0.24 \\
(0.77)\end{array}$ & \\
\hline Hedge fund & & $\begin{array}{l}-1.05^{* *} \\
(-2.19)\end{array}$ & \\
\hline U.S. based & & $\begin{array}{l}-1.35^{* * * *} \\
(-3.02)\end{array}$ & \\
\hline Age 40 and below & & & $\begin{array}{c}0.44 \\
(1.31)\end{array}$ \\
\hline Male & & & $\begin{array}{c}-0.02 \\
(-0.03)\end{array}$ \\
\hline $\mathrm{PhD}$ or master's degree & & & $\begin{array}{l}-0.86^{* *} \\
(-2.47)\end{array}$ \\
\hline$N$ & 277 & 272 & 188 \\
\hline$\chi^{2}(p$-value $)$ & $\begin{array}{c}7.34 \\
(0.06)\end{array}$ & $\begin{array}{l}22.13 \\
(0.00)\end{array}$ & $\begin{array}{l}12.39 \\
(0.05)\end{array}$ \\
\hline Pseudo- $R^{2}$ & 0.013 & 0.038 & 0.032 \\
\hline
\end{tabular}




\section{Table 7. Institutional investors' view on pecking order theory}

This table summarizes the survey responses on the impact of different types of security offerings on valuation and the demand for stocks. The responses to the first four questions are measured on a five-point Likert scale ranging from one for strongly disagree to five for strongly agree. The first three columns present the means, the percentage of respondents choosing 4 or 5, and the number of observations. The respondents also had an opportunity to choose the "don't know/don't want to answer" alternative; these responses are excluded from the calculations. We mention the responses by order of importance, which does not necessarily correspond to the order of the statements in the survey. Size refers to assets under management of the respondent's employer. The last four questions on the factors affecting perceived valuation were only asked to the respondents who agreed (answered 4 or 5) that they revise their stock valuations downward following a security offering. The responses to these questions are measured using the alternatives yes, no, and "don't know," the latter response being excluded from all the calculations. The superscripts ${ }^{* * *},{ }^{* *}$, and ${ }^{*}$ indicate statistical significance at the $1 \%$, $5 \%$, and $10 \%$ levels, respectively, in two-tailed $t$-tests for the difference of means between every two subgroups of respondents.

\begin{tabular}{|c|c|c|c|c|c|c|c|c|c|c|c|c|c|c|c|}
\hline & \multicolumn{3}{|c|}{ All } & \multicolumn{2}{|c|}{ Age } & \multicolumn{2}{|c|}{ Gender } & \multicolumn{2}{|c|}{ Size } & \multicolumn{2}{|c|}{ Education } & \multicolumn{2}{|c|}{ Country } & \multicolumn{2}{|c|}{ Type of fund } \\
\hline & Mean & $\begin{array}{c}\% 4 \\
\text { and } 5\end{array}$ & $N$ & $\begin{array}{l}40 \text { and } \\
\text { under }\end{array}$ & $\begin{array}{c}41 \text { and } \\
\text { over }\end{array}$ & Male & Other & $\begin{array}{l}\text { Under } \\
10 \text { bn } \\
\text { AUD }\end{array}$ & $\begin{array}{l}\text { Over } \\
10 \text { bn } \\
\text { AUD }\end{array}$ & $\begin{array}{c}\mathrm{PhD} \text { or } \\
\mathrm{MSc}\end{array}$ & Other & U.S. & Other & $\begin{array}{l}\text { Hedge } \\
\text { fund }\end{array}$ & Other \\
\hline \multicolumn{16}{|l|}{ Panel A. } \\
\hline \multicolumn{16}{|l|}{$\begin{array}{l}\text { Impact of security offerings on } \\
\text { valuation and demand for equities: }\end{array}$} \\
\hline $\begin{array}{l}\text { - When a company announces an } \\
\text { equity offering, I usually revise my } \\
\text { valuation of its stock price downward } \\
\text { and/or sell some of its stock }\end{array}$ & 2.97 & 27.20 & 125 & 2.84 & 3.06 & 2.93 & 3.00 & 2.98 & 3.00 & 2.98 & 2.91 & 3.29 & 2.96 & 3.07 & 2.95 \\
\hline $\begin{array}{l}\text { - When a company announces a } \\
\text { convertible bond offering, I usually } \\
\text { revise my valuation of its stock price } \\
\text { downward and/or sell some of its stock }\end{array}$ & 2.92 & 23.58 & 123 & 2.81 & 3.00 & 2.91 & 2.50 & 3.01 & 2.78 & 2.98 & 2.84 & 3.14 & 2.91 & 3.00 & 2.91 \\
\hline $\begin{array}{l}\text { - When a company announces a } \\
\text { straight bond offering, I usually revise } \\
\text { my valuation of its stock price } \\
\text { downward and/or sell some of its stock }\end{array}$ & 2.54 & 8.20 & 122 & 2.38 & 2.58 & 2.46 & 3.00 & 2.61 & 2.44 & 2.65 & 2.36 & 2.57 & 2.54 & 2.43 & 2.56 \\
\hline $\begin{array}{l}\text { Equity dilution concerns for existing } \\
\text { shareholders }\end{array}$ & 4.45 & 90.47 & 126 & 4.61 & 4.40 & 4.52 & 4.50 & $4.54^{*}$ & 4.26 & 4.46 & 4.56 & 4.29 & 4.46 & 4.40 & 4.46 \\
\hline
\end{tabular}


Panel B. Downward valuation revision at equity offering announcement will be stronger if

\begin{tabular}{|c|c|c|c|c|c|c|c|c|c|c|c|c|c|}
\hline & $\begin{array}{c}\% \\
\text { agree }\end{array}$ & $V$ & & & & & & & & & & & \\
\hline $\begin{array}{l}\text { - Less information is available about } \\
\text { the company's asset value }\end{array}$ & 88.46 & 26 & 100.00 & 83.33 & NA & $100.00^{* *}$ & 70.00 & 87.50 & 93.33 & $33.33^{* * * *}$ & 95.65 & 100.00 & 86.36 \\
\hline - Fewer growth opportunities & 88.24 & 34 & 93.75 & 92.86 & NA & 86.36 & 91.67 & 100.00 & 90.48 & 100.00 & 87.50 & 100.00 & 86.21 \\
\hline - Larger issue size & 81.82 & 33 & 73.33 & 85.71 & NA & 81.82 & 81.82 & 87.50 & 76.19 & 100.00 & 80.65 & 80.00 & 82.14 \\
\hline - Large cash reserves & 54.55 & 33 & 60.00 & 38.46 & NA & 57.14 & 50.00 & $85.71^{* *}$ & 38.10 & 50.00 & 54.84 & 40.00 & 57.14 \\
\hline
\end{tabular}




\section{Table 8. Institutional investors' view on market timing theory}

This table summarizes the importance of market timing behavior as perceived by institutional investors. The responses are measured on a five-point Likert scale ranging from one for strongly disagree to five for strongly agree. The first three columns present the means, the percentage of respondents choosing 4 or 5 , and the number of observations.

The respondents also had an opportunity to choose the "don't know/don't want to answer" alternative; these responses are excluded from the calculations. Size refers to assets under management of the respondent's employer. We mention the responses by order of importance, which does not necessarily correspond to the order of the statements in the survey. The superscripts ${ }^{* * *},{ }^{* *}$, and ${ }^{*}$ indicate statistical significance at the $1 \%, 5 \%$, and $10 \%$ levels, respectively, in two-tailed $t$-tests for the difference of means between every two subgroups of respondents.

\begin{tabular}{|c|c|c|c|c|c|c|c|c|c|c|c|c|c|c|c|}
\hline & \multicolumn{3}{|c|}{ All } & \multicolumn{2}{|c|}{ Age } & \multicolumn{2}{|c|}{ Gender } & \multicolumn{2}{|c|}{ Size } & \multicolumn{2}{|c|}{ Education } & \multicolumn{2}{|c|}{ Country } & \multicolumn{2}{|c|}{ Type of fund } \\
\hline & Mean & $\begin{array}{c}\% 4 \\
\text { and } 5\end{array}$ & $N$ & $\begin{array}{l}40 \text { and } \\
\text { under }\end{array}$ & $\begin{array}{c}41 \text { and } \\
\text { over }\end{array}$ & Male & Other & $\begin{array}{l}\text { Under } \\
10 \text { bn } \\
\text { AUD }\end{array}$ & $\begin{array}{l}\text { Over } \\
10 \text { bn } \\
\text { AUD }\end{array}$ & $\begin{array}{l}\mathrm{PhD} \\
\text { or } \\
\mathrm{MSc}\end{array}$ & Other & U.S. & Other & $\begin{array}{l}\text { Hedge } \\
\text { fund }\end{array}$ & Other \\
\hline Firms try to time: & & & & & & & & & & & & & & & \\
\hline $\begin{array}{l}\text { Equity offerings when equity } \\
\text { market valuations are high }\end{array}$ & 4.07 & 79.40 & 165 & 4.09 & 4.03 & 4.04 & 4.57 & $4.19^{*}$ & 3.91 & 4.03 & 4.09 & $3.69^{*}$ & 4.12 & 4.06 & 4.07 \\
\hline $\begin{array}{l}\text { - Straight bond offerings when } \\
\text { interest rates are low }\end{array}$ & 3.78 & 68.35 & 158 & 3.86 & 3.71 & 3.78 & 4.25 & 3.71 & 3.90 & 3.88 & 3.72 & 3.93 & 3.77 & 3.53 & 3.81 \\
\hline $\begin{array}{l}\text { Convertible offerings when } \\
\text { equity market valuations are } \\
\text { high }\end{array}$ & 3.61 & 61.19 & 152 & 3.67 & 3.55 & 3.61 & 4.00 & 3.58 & 3.66 & $3.79^{* *}$ & 3.48 & 3.85 & 3.59 & 3.36 & 3.63 \\
\hline $\begin{array}{l}\text { Convertible bond offerings } \\
\text { when interest rates are low }\end{array}$ & 3.47 & 54.19 & 155 & $3.67^{\text {**** }}$ & 3.22 & 3.47 & 3.67 & 3.42 & 3.57 & $3.64^{*}$ & 3.33 & 3.62 & 3.46 & $2.93^{* *}$ & 3.52 \\
\hline $\begin{array}{l}\text { - Convertible bond offerings } \\
\text { when volatility is high }\end{array}$ & 3.01 & 24.50 & 151 & 3.08 & 2.90 & 2.98 & 3.50 & 2.94 & 3.11 & 3.05 & 2.95 & $3.67^{* * *}$ & 2.96 & 2.93 & 3.02 \\
\hline
\end{tabular}




\section{Table 9. Institutional investors' view on financial constraints}

This table summarizes the importance of financial constraints in investments and the metrics used to measure financial constraints. The responses are measured on a five-point Likert scale ranging from one for not at all important to five for extremely important. The first three columns present the means, the percentage of respondents ranking each factor at 4 or 5 , and the number of observations. In all the questions, the respondents also had an opportunity to choose the "don't know/don't want to answer" alternative; these responses are excluded from the calculations. Questions regarding separate measures of financial constraints are only addressed to the respondents who chose 3, 4, or 5 in the question on the importance of financial constraints. We mention the responses by order of importance, which does not necessarily correspond to the order of the statements in the survey. Size refers to assets under management of the respondent's employer. The superscripts ${ }^{* * * * *},{ }^{* *}$, and ${ }^{*}$ indicate statistical significance at the $1 \%, 5 \%$, and $10 \%$ levels, respectively, in two-tailed $t$-tests for the difference of means between every two subgroups of respondents.

\begin{tabular}{|c|c|c|c|c|c|c|c|c|c|c|c|c|c|c|c|}
\hline & \multicolumn{3}{|c|}{ All } & \multicolumn{2}{|c|}{ Age } & \multicolumn{2}{|c|}{ Gender } & \multicolumn{2}{|c|}{ Size } & \multicolumn{2}{|c|}{ Education } & \multicolumn{2}{|c|}{ Country } & \multicolumn{2}{|c|}{ Type of fund } \\
\hline & Mean & $\begin{array}{c}\% 4 \\
\text { and } 5\end{array}$ & $N$ & $\begin{array}{l}40 \text { and } \\
\text { under }\end{array}$ & $\begin{array}{l}41 \text { and } \\
\text { over }\end{array}$ & Male & Other & $\begin{array}{l}\text { Under } \\
10 \text { bn } \\
\text { AUD }\end{array}$ & $\begin{array}{l}\text { Over } \\
10 \text { bn } \\
\text { AUD }\end{array}$ & $\begin{array}{l}\mathrm{PhD} \\
\text { or } \\
\mathrm{MSc}\end{array}$ & Other & U.S. & Other & $\begin{array}{l}\text { Hedge } \\
\text { fund }\end{array}$ & Other \\
\hline $\begin{array}{l}\text { Importance of financial constraints } \\
\text { in decision to invest } \\
\text { Measures of financial constraints: }\end{array}$ & 3.51 & 52.38 & 189 & 3.48 & 3.53 & 3.50 & 3.44 & 3.52 & 3.48 & $3.33^{* *}$ & 3.65 & $2.94^{* *}$ & 3.55 & 3.18 & 3.54 \\
\hline - Leverage & 4.18 & 84.42 & 154 & 4.24 & 4.16 & 4.20 & 4.25 & 4.15 & 4.22 & 4.11 & 4.28 & 4.00 & 4.18 & 4.15 & 4.18 \\
\hline $\begin{array}{l}\text { - Ratio of cash flow to total } \\
\text { assets }\end{array}$ & 4.01 & 79.87 & 154 & $4.17^{* *}$ & 3.87 & 4.04 & 3.88 & 4.06 & 3.94 & 4.06 & 4.01 & 3.83 & 4.01 & $3.62^{*}$ & 4.04 \\
\hline - $\quad$ Sales growth of the firm & 3.53 & 53.89 & 154 & 3.60 & 3.44 & 3.51 & 3.88 & 3.60 & 3.42 & $3.29^{* * * *}$ & 3.76 & 3.17 & 3.55 & 3.23 & 3.55 \\
\hline - $\quad$ Stock market listing & 3.42 & 48.63 & 146 & $3.27^{*}$ & 3.64 & $3.52^{* * *}$ & 2.14 & $3.58^{*}$ & 3.23 & 3.29 & 3.56 & $4.13^{*}$ & 3.39 & 3.85 & 3.38 \\
\hline $\begin{array}{l}\text { - Ratio of cash balance to total } \\
\text { assets }\end{array}$ & 3.29 & 45.75 & 153 & 3.40 & 3.21 & 3.30 & 3.50 & 3.38 & 3.22 & 3.38 & 3.27 & 3.08 & 3.31 & $2.75^{* *}$ & 3.34 \\
\hline - $\quad$ Sales growth of the industry & 3.12 & 36.36 & 154 & 3.14 & 3.10 & $3.09^{* *}$ & 3.88 & 3.17 & 3.08 & 3.05 & 3.20 & 2.75 & 3.16 & 3.23 & 3.11 \\
\hline - $\quad$ Credit rating & 3.01 & 35.30 & 153 & $2.82^{* *}$ & 3.21 & 2.98 & 3.38 & 2.95 & 3.09 & 2.92 & 3.05 & 2.58 & 3.05 & 2.92 & 3.01 \\
\hline - Firm size & 2.94 & 28.10 & 153 & 2.90 & 2.98 & 2.94 & 2.63 & 2.85 & 3.06 & $3.18^{* * * *}$ & 2.72 & 2.75 & 2.97 & 2.69 & 2.96 \\
\hline $\begin{array}{l}\text { - Ratio of dividends to total } \\
\text { assets }\end{array}$ & 2.84 & 26.31 & 152 & 2.84 & 2.90 & 2.85 & 3.13 & 2.84 & 2.86 & 2.89 & 2.86 & $2.33^{*}$ & 2.90 & $2.31^{*}$ & 2.89 \\
\hline - $\quad$ Industry peers' debt ratios & 2.78 & 19.61 & 153 & 2.83 & 2.69 & 2.77 & 2.75 & 2.67 & 2.92 & 2.84 & 2.72 & 2.92 & 2.78 & 2.92 & 2.76 \\
\hline - $\quad$ Firm age & 2.05 & 8.05 & 149 & 2.03 & 2.05 & 2.05 & 1.88 & 2.11 & 2.00 & 2.05 & 2.07 & 1.92 & 2.07 & 2.08 & 2.05 \\
\hline
\end{tabular}




\section{Appendix: Questionnaire}

\section{Questions about the participant}

Q1. How would you characterize the institution for which you work? Please tick the answer that closest describes your institution.

$1=$ Superannuation fund

$2=$ Pension fund

$3=$ Insurance company

$4=$ Mutual fund

$5=$ Hedge fund specialized in convertible arbitrage

$6=$ Hedge fund specialized in other strategies than convertible arbitrage

$7=$ Other (please specify)

Q2. In which category below is the approximate amount of assets under management for your institution, in millions of AUD? If you work for an Australian subsidiary of an international fund manager, please give the total AUD for the parent firm.

$1=$ Less than 50 million AUD

$2=$ Between 50 million and 500 million AUD

$3=$ Between 500 million and 1 billion AUD

4 = Between 1 billion and 10 billion AUD

$5=$ More than 10 billion AUD

$6=$ More than 100 billion AUD

Q3. In which country are the headquarters of (the parent company) of your institution?

$1=$ Australia

$2=$ U.S.

$3=\mathrm{U} \cdot \mathrm{K}$.

$4=$ Other (please specify)

Q4. Are you responsible for selecting any of the following securities? Please tick all that apply.

$1=$ Stocks of individual listed companies

$2=$ Government bonds

$3=$ Convertible bonds of individual companies

$4=$ Ordinary (straight) bonds of individual companies 
$5=$ Money market investments

$6=$ Other (please specify)

The following text will appear after this question is answered: In our project we intend to investigate investors' opinions and potential influence on corporate capital structure, securities issuance, and security design. Hence, most of the questions that follow are on these topics.

Q5 is only asked to respondents who ticked 1 in Q4.

Q5. What is your role in decisions to invest in stocks of individual companies? Please select the alternative that is closest to your situation.

$1=$ My fund does not employ anybody to look at the balance sheets of individual companies.

$2=$ My fund works with committees or teams and I am the chief investment officer.

$3=$ My fund works with committees or teams and I am one of the members who advises the chief investment officer.

$4=\mathrm{I}$ am the sole decision maker for the selection of stocks for my fund.

$5=$ I only represent my employer at annual meetings of the companies in which we invest.

$6=$ None of the above applies. (Please specify your role.)

Q6 is only asked to respondents who ticked 3 in Q4.

Q6. What is your role in decisions to invest in convertible bonds? Please select the alternative that is closest to your situation.

$1=$ My fund does not employ anybody to look at the balance sheets of individual companies.

$2=$ My fund works with committees or teams and I am the chief investment officer.

$3=$ My fund works with committees or teams and I am one of the members who advises the chief investment officer.

$4=\mathrm{I}$ am the sole decision maker for the selection of convertible bonds for my fund.

$5=\mathrm{I}$ only represent my employer at annual meetings of the companies in which we invest.

$6=$ None of the above applies. (Please specify your role.)

$Q 7$ is only asked to respondents who ticked 4 in $Q 4$.

Q7. What is your role in decisions to invest in ordinary (straight) bonds? Please select the alternative that is closest to your situation.

$1=$ My fund does not employ anybody to look at the balance sheets of individual companies.

$2=$ My fund works with committees or teams and I am the chief investment officer.

$3=$ My fund works with committees or teams and I am one of the members who advises the chief investment officer.

4 = I am the sole decision maker for the selections of straight bonds for my fund.

$5=\mathrm{I}$ only represent my employer at annual meetings of the companies in which we invest.

$6=$ None of the above applies. (Please specify your role.) 


\section{Questions on capital structure}

Q8 is only asked to respondents who ticked 1 in Q4.

Q8. When deciding to invest in shares of individual companies, how important is the capital structure (or the amount of debt versus equity) of the underlying company to you?

Rating scale:

$1=$ not at all important; 2 = slightly important; 3 = moderately important; 4 = very important;

$5=$ extremely important

Q9 is only asked to respondents who ticked 3 in Q4.

Q9. When deciding to invest in convertible bonds, how important is the capital structure (or the amount of debt versus equity) of the underlying company to you?

Rating scale:

$1=$ not at all important; 2 = slightly important; 3 = moderately important; 4 = very important; $5=$ extremely important

Q10 is only asked to respondents who ticked 4 in $Q 4$.

Q10. When deciding to invest in ordinary (straight) bonds of individual companies, how important is the capital structure (or the amount of debt versus equity) of the underlying company to you?

Rating scale:

$1=$ not at all important; 2 = slightly important; 3 = moderately important; 4 = very important; $5=$ extremely important

Q11 is only asked to respondents who did not tick either 1, 3, or 4 in Q4.

Q11. When deciding to invest in individual companies, how important is the capital structure (or the amount of debt versus equity) of the underlying company to you?

Rating scale:

$1=$ not at all important; 2 = slightly important; 3 = moderately important; 4 = very important;

$5=$ extremely important

Q12. Insofar as you take capital structure into account when deciding whether to invest in a company, how important are the following factors to you?

Rating scale for each factor:

$1=$ not at all important; 2 = slightly important; 3 = moderately important; 4 = very important;

5 = extremely important; N/A = don't know/don't want to answer

$1=$ The company maximizing the corporate tax deductibility of interest 
2 = The company not having so much debt that it risks the possibility of bankruptcy or associated financial distress costs

$3=$ The company not having so much debt that there is a chance of underinvestment in projects with a positive net present value

$4=$ The company not having so much debt that its management might be tempted to invest in too risky, negative net present value projects (i.e., projects with a small chance of a very high payoff)

$5=$ The company having sufficient debt, so as to avoid managers wasting corporate cash on pet projects and perks such as negative net present value acquisitions that increase managerial prestige, large offices, corporate jets, etc.

$6=$ The company not having so much debt that it runs the risk of losing customers and suppliers because of financial uncertainty

$7=$ The company having approximately the same debt ratio as its industry peers

$8=$ The company maintaining its financial flexibility.

Q13 is only asked to respondents who ticked 1 in $Q 4$.

Q13. This question deals with the impact of firms' announcements of security offerings on your stock price valuations. Please indicate whether you agree with the following statements.

Rating scale:

$1=$ strongly disagree $; 2=$ somewhat disagree; $3=$ neither agree nor disagree $; 4=$ somewhat agree; 5 = strongly agree; N/A = don't know/don't want to answer

$1=$ When a company announces an equity offering, I usually revise my valuation of its stock price downward and/or sell some of its stock.

$2=$ When a company announces a convertible bond offering, I usually revise my valuation of its stock price downward and/or sell some of its stock.

$3=$ When a company announces a straight bond offering, I usually revise my valuation of its stock price downward and/or sell some of its stock.

4 = An important concern I have when firms are announcing equity or convertible bond offerings is the degree of equity dilution for their existing shareholders.

Q14 is only asked to respondents who chose 4 or 5 for Q13.1 or Q13.2.

Q14. Please answer yes, no, or "don't know" to each of the following statements. My downward price revision and/or stock sale due to a new equity or convertible bond offering is particularly large if

$1=$ The issuing company has large cash reserves

$2=$ The issuing company has few valuable growth opportunities. 
$3=$ The issue size is large.

$4=$ I have relatively little information about the company's asset value.

Q15. Firms are defined as financially constrained if it is considerably cheaper for them to use internal funds than to use external funds. How important is it to you whether the company in which you are considering investing has any financial constraints, after taking into account all other factors, such as credit ratings?

Rating scale:

$1=$ not at all important

$2=$ slightly important

3 = moderately important;

4 = very important;

$5=$ extremely important

$\mathrm{NA}=$ don't know/don't want to answer

Q16 is only asked to respondents who answered 3, 4, or 5 for Q15.

Q16. As far as you find financial constraints important when deciding whether to invest in a company, how important are the following factors to you? Please only respond with regard to using these measures for financial constraints. For example, if you look at the company's age as a measure of reputation, but do not consider age as a measure of financial constraint at all, choose the alternative "not at all important."

Rating scale for each measure:

1 = not at all important; 2 = slightly important; 3 = moderately important; 4 = very important; 5 = extremely important; N/A = don't know/don't want to answer

$1=$ The age of the company (older means less financially constrained)

$2=$ The company's size (larger firm size means less financially constrained)

$3=$ The ratio of cash flow to total assets (higher cash flow means less financially constrained)

$4=$ The company's leverage

$5=$ The ratio of dividends to total assets (higher dividends means less financially constrained)

$6=$ The ratio of cash balance to total assets (higher cash balance means less financially constrained)

$7=$ The sales growth of the industry in which the firm operates (higher industry growth means more financially constrained)

$8=$ The firm's sales growth (higher growth means less financially constrained) 
$9=$ Whether the firm has a stock market listing (being quoted on the stock market means less financially constrained)

$10=$ Whether the firm has a credit rating (having a credit rating means less financially constrained

$11=$ Whether the firm's industry peers have large debt ratios (large debt ratios for peers mean that the firm itself is less financially constrained)

\section{Question on market timing}

Q17. This question relates to whether companies time their security offerings to occur during particular (macroeconomic) market conditions. Please indicate whether you agree with the following statements.

Rating scale:

$1=$ strongly disagree; $2=$ somewhat disagree; $3=$ neither agree nor disagree; $4=$ somewhat agree; 5 = strongly agree; N/A = don't know/don't want to answer.

$1=$ Firms try to time their equity offerings during periods when equity market valuations are high.

$2=$ Firms try to time their convertible offerings during periods when equity market valuations are high.

$3=$ Firms try to time their straight bond offerings during periods when interest rates are low.

$4=$ Firms try to time their convertible bond offerings during periods when interest rates are low.

$5=$ Firms try to time their convertible bond offerings during periods when volatility is high.

\section{Questions on the supply side of the market}

Q18. How important is it to you that the company in which you are considering investing have a credit rating from one of the credit rating agencies, such as Moody's or Standard \& Poor's, when considering the following securities?

Rating scale for each security:

1 = not at all important; 2 = slightly important; 3 = moderately important; 4 = very important;

5 = extremely important; N/A = don't know/don't want to answer.

$1=$ Common shares

$2=$ Convertible bonds

$3=$ Ordinary (= non-convertible $)$ bonds 
Q19 is only asked to respondents who ticked 4 on $Q 4$.

Q19. Suppose that you are considering buying straight bonds in a company that does not have a credit rating from a market leading credit rating agency, such as Moody's or Standard \& Poor's. How would it affect your investment decision? Please choose one alternative.

$1=\mathrm{I}$ would buy the bonds if they offered the same yield as similarly rated bonds.

$2=$ I would buy the bonds, but only if I could obtain a small yield surplus ( $0-2 \%$ over similarly rated bonds).

3 = I would only buy the bonds if I could obtain a large yield surplus (larger than $2 \%$ over similarly rated bonds.

4 = I would never invest in unrated bonds, no matter how safe and attractive the issuing company looks otherwise, even though my institution does not have an explicit policy of not investing in these types of securities.

$5=$ My institution has a policy of not investing in unrated bonds.

$6=$ Don't know/don't want to answer.

Q20 is only asked tofak respondents who ticked 3 on Q4.

Q20. Suppose that you are considering buying convertible bonds in a company that does not have a credit rating from a market leading credit rating agency, such as Moody's or Standard $\&$ Poor's. How would it affect your investment decision? Please choose one alternative.

$1=\mathrm{I}$ would buy the bonds if they offered the same yield as similarly rated bonds.

$2=$ I would buy the bonds, but only if I could obtain a small yield surplus ( $0-2 \%$ over similarly rated bonds).

3 = I would only buy the bonds if I could obtain a large yield surplus (larger than $2 \%$ over similarly rated bonds.

4 = I would never invest in unrated bonds, no matter how safe and attractive the issuing company looks otherwise, even though my institution does not have an explicit policy of not investing in these types of securities.

$5=$ My institution has a policy of not investing in unrated bonds.

$6=$ Don't know/don't want to answer.

Q21. Please indicate whether you agree or disagree with the following statements.

Rating scale for each statement:

$1=$ strongly disagree; $2=$ somewhat disagree; $3=$ neither agree nor disagree; $4=$ somewhat agree; $5=$ strongly agree; N/A = don't know/don't want to answer

$1=$ Investor demand has a strong influence on a firm's choice of what security types to issue (i.e., equity, convertibles, or straight bonds). 
$2=$ Investor demand has a strong influence on the amount of financing that firms raise for their security offerings.

3 = Investor demand has a strong influence on the design of convertible bonds, for example, on conversion premium and callability.

4 = Investor demand has a strong influence on the design of straight bonds, for example, on their time to maturity, coupon rate, and callability.

$5=$ Firms make their security issuance decisions based mostly on their own firm characteristics, needs, and macroeconomic circumstances. Investor preferences are not of great influence.

$6=$ Firms make their security design decisions based mostly on their own firm characteristics, needs, and macroeconomic circumstances. Investor preferences are not of great influence.

\section{Open question}

Q22. One of the key unsolved puzzles in the academic literature is whether and how investors such as yourself can influence corporate capital structure, securities issuance, and security design decisions. We would highly appreciate any additional insights from you on this matter. For example, we would like to know the following:

a. To what extent do you believe that corporate security choices are influenced by corporate characteristics versus investor preferences? Can you put a percentage estimate on how large you think the impact of investor preferences is relative to the impact of firm characteristics and overall macroeconomic conditions?

b. If you believe you can indeed influence securities issuance and/or design decisions, as an investor, how do you exert this influence in practice? Is it by talking with the corporations in which you invest? Or indirectly, via the investment bank? Or, importantly, are there any channels of influence that we are overlooking in this survey?

c. What types of firms are more open/prone to influence from investors such as yourself? Is it younger firms, more constrained firms, or smaller firms? Any insights on this matter are highly appreciated.

Finally, we have some questions about yourself. We would like to use these answers to see if there are patterns in the responses that relate to certain personalities. You can feel free to skip these questions if you do not want to answer them.

Q23. In which age category are you?

$1=$ Younger than 30 years

$2=$ From 31 to 40 years

$3=$ From 41 to 50 years

$4=$ From 51 to 60 years

$5=61$ years or older

$6=$ Choose not to disclose

Q24. What is the highest level of education that you obtained?

$1=\mathrm{PhD}$ 
$2=$ MBA

$3=$ Master's degree

$4=$ Bachelor's degree

$5=$ No university education

$6=$ Choose not to disclose

Q25. What is your gender?

$1=$ Male

$2=$ Female

$3=$ Transgender

4 = Choose not to disclose

Thank you for your participation! If you would like to be included in the prize drawing, please submit your e-mail address below. 